\title{
Potential impacts of finfish aquaculture on eelgrass (Zostera marina) beds and possible monitoring metrics for management: a case study in Atlantic Canada
}

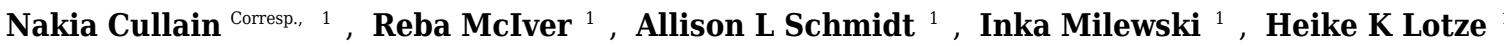 \\ 1 Department of Biology, Dalhousie University, Halifax, Canada \\ Corresponding Author: Nakia Cullain \\ Email address: nakia@zavoralab.com
}

Eelgrass (Zostera marina) has been designated an Ecologically Significant Species in Atlantic Canada. The development and rapid expansion of netpen finfish aquaculture into sensitive coastal habitats has raised concerns about the impacts of finfish aquaculture on eelgrass habitats. To date, no studies have been done in Atlantic Canada to examine these impacts or to identify potential monitoring variables that would aid in the development of specific conservation and management objectives. As a first step in addressing this gap, we examined differences in environmental variables, eelgrass bed structure and macroinfauna communities at increasing distances from a finfish farm in Port Mouton Bay, a reference site in adjacent Port Joli Bay, and published survey results from other sites without finfish farms along the Atlantic Coast of Nova Scotia. Drawing on research done elsewhere and our results, we then identified possible metrics for assessing and monitoring local impacts of finfish aquaculture on eelgrass habitats. Our results suggest some nutrient and organic enrichment, higher epiphyte loads, lower eelgrass cover and biomass, and lower macroinfauna biomass closer to the farm. Moreover, community structure significantly differed between sites with some species increasing and others decreasing closer to the farm. Changes in the macroinfauna community could be linked to observed differences in environmental and eelgrass bed variables. These results provide new insights into the potential impacts of finfish aquaculture on eelgrass habitats in Atlantic Canada. We recommend a suite of measures for assessment and monitoring that take into account response time to disturbance and account for different levels of eelgrass organizational response (from physiological to community). 
1 Potential impacts of finfish aquaculture on eelgrass (Zostera marina) beds and possible 2 monitoring metrics for management: a case study in Atlantic Canada.

3

4 5

6 7

8 *corresponding author: email: nakia@zavoralab.com; phone: +258 87-174-7934

9 Current address: Zavora Marine Lab, Zavora Beach, Inharrime, Inhambane, Mozambique

\section{ABSTRACT}

12 Eelgrass (Zostera marina) has been designated an Ecologically Significant Species in Atlantic

13 Canada. The development and rapid expansion of netpen finfish aquaculture into sensitive coastal habitats has raised concerns about the impacts of finfish aquaculture on eelgrass habitats. To date, no studies have been done in Atlantic Canada to examine these impacts or to identify potential monitoring variables that would aid in the development of specific conservation and management objectives. As a first step in addressing this gap, we examined differences in environmental variables, eelgrass bed structure and macroinfauna communities at increasing distances from a finfish farm in Port Mouton Bay, a reference site in adjacent Port Joli Bay, and published survey results from other sites without finfish farms along the Atlantic Coast of Nova Scotia. Drawing on research done elsewhere and our results, we then identified possible metrics for assessing and monitoring local impacts of finfish aquaculture on eelgrass habitats. Our results suggest some nutrient and organic enrichment, higher epiphyte loads, lower eelgrass cover and biomass, and lower macroinfauna biomass closer to the farm. Moreover, community structure significantly differed between sites with some species increasing and others decreasing closer to the farm. Changes in the macroinfauna community could be linked to observed differences in environmental and eelgrass bed variables. These results provide new insights into the potential impacts of finfish aquaculture on eelgrass habitats in Atlantic Canada. We recommend a suite of measures for assessment and monitoring that take into account response time to disturbance and account for different levels of eelgrass organizational response (from physiological to community). 


\section{INTRODUCTION}

34 Seagrass beds are among the most productive and diverse ecosystems on the planet (Larkum et al. 2006); however, they continue to be threatened by anthropogenic activities around the world (Orth et al., 2006; Waycott et al., 2009; Short et al., 2011). Discharge of nutrients and accumulation of organic matter from human sources, such as municipal and industrial wastewater and land run-off are some of the most influential causes of degradation to seagrass habitats in coastal waters (Hauxwell, Cebrian, Valiela 2003; Waycott et al., 2009; Schmidt et al., 2012). Over the past two decades, the development and rapid expansion of finfish aquaculture (such as open netpens) into sensitive coastal habitats has further increased the risk of degradation to seagrasses (Duarte, 2002; Vandermeulen, 2005; Holmer et al., 2008).

The impacts of marine fish farms on seagrass beds have been examined extensively, but not exclusively, on Posidonia oceanica meadows in the Mediterranean Sea (Table 1). These studies have shown that increased nutrient loading, organic matter and sedimentation rates resulting from fish farm activities can lead to changes in seagrass physiology (e.g. nitrogen uptake, carbon sequestration), their plant and canopy structure (e.g., leaf morphometrics, shoot density, biomass), the size of seagrass meadows (e.g., decrease in cover, disappearance), as well as changes in their associated flora (e.g., epiphyte loads, algal growth) and fauna (e.g., abundance, composition, diversity) (Table 1) and sediment composition and chemistry (e.g., \% organic matter, sulphides, primary production; Holmer et al., 2008). The distance at which effects from a fish farm can be measured vary with the environmental variable being measured and the intensity and duration of farming, husbandry practises and local oceanographic conditions (Holmer et al., 2008; Karakassis et al., 2013).

Zostera marina, commonly known as eelgrass, is the dominant species of seagrass in Atlantic Canada (Short et al., 2011). It has been designated an Ecologically Significant Species (ESS) due to its crucial role in providing essential habitat for numerous species and other key ecological services, including nutrient cycling, carbon sequestration, and reduction of wave action (DFO, 2009a, 2012). With their extensive root and rhizome system, eelgrass beds also stabilize sediments and provide a rich food source and habitat for infauna communities (Orth et al., 1984;

61 Boström \& Bonsdorff, 1997). Unlike seagrasses in the Mediterranean Sea that occur at depths down to 40-45 m (Telesca et al., 2015), eelgrass meadows along the Atlantic Coast of Canada 
63 are found at shallower depths (1-12 m; DFO, 2009a) due to stronger light limitation in temperate 64 waters (Hemminga \& Duarte, 2000). Since open netpen fish farms in Atlantic Canada typically 65 require a minimum depth of $12 \mathrm{~m}$ (net depth plus $3 \mathrm{~m}$ clearance from bottom; Hargrave, 2002), 66 eelgrass meadows are generally not located directly under, but adjacent to, fish pens.

The potential impacts of finfish aquaculture on eelgrass beds in Canada have been acknowledged for more than a decade (Vandermeulen, 2005). Several zones of potential impacts have been identified: eelgrass closest to a finfish farm (Zone A) is likely to be dead or dying and covered in epiphytes, bacterial or fungal mats; eelgrass at some undetermined intermediate distance from a farm (Zone B) is likely to have reduced growth and heavy to moderate epiphyte loads and benthic algal mats; and eelgrass even further from a fish farm (Zone $\mathrm{C}$ ) is expected to have minimal or even positive growth due to nutrient enrichment (Vandermeulen, 2005). To date, however, there have been no quantitative studies in Atlantic Canada to describe the potential impacts of finfish aquaculture on eelgrass habitats, to delineate the width of different impact zones, or to assess potential monitoring variables that would aid in the development of specific conservation and management objectives.

As a first step towards addressing these gaps, the objectives of this study were to (i) assess the changes in eelgrass bed structure and associated macroinfaunal communities at increasing distances from a finfish farm in Port Mouton Bay, and a reference site in adjacent Port Joli Bay, Nova Scotia, (ii) link the observed changes in macroinfauna to changes in environmental and eelgrass bed variables, and (iii) suggest possible monitoring metrics for assessing and managing the impacts of finfish aquaculture on eelgrass habitat. We also place our results in a broader context by comparing them to published eelgrass bed surveys from other sites without fish farms on the Atlantic Coast of Canada (Cullain et al., 2017) and to published studies on fish farm effects on seagrass beds in the Mediterranean (Table 1). The Port Mouton fish farm has been in operation since 1995; however, a super chill event killed most fish five months prior to our sampling in 2015, which potentially reduced the immediate short-term but not the long-term impacts being observed. Overall, our study provides insights into changes in eelgrass habitats near a finfish farm in Atlantic Canada and we suggest possible metrics for assessing and monitoring local and broader-scale impacts of fish farms on these ecosystems. 


\section{Study area}

95 Our study sites were located along the Atlantic Coast of Nova Scotia (Table 2, Fig. 1). Port

96 Mouton Bay, site of the finfish farm, is a partially sheltered bay covering an area of $55.6 \mathrm{~km}^{2}$

97 (Fig. 1). Tides, averaging $1.5 \mathrm{~m}$, are semi-diurnal and water depth throughout the bay ranges

98 from 8-18 m. Tidal currents tend to be low (2-3 $\mathrm{cm} \mathrm{s}^{-1}$, Gregory et al., 1993) and surface currents

99 are strongly influenced by winds (DFO, 2007, 2009b). During our sampling period (July 14-21,

100 2015), sea surface temperatures were quite similar at our four sites $\left(12-15^{\circ} \mathrm{C}\right)$ and sampling depth

101 in eelgrass beds ranged from 1.7-2.9 m. These are typical conditions for eelgrass habitats in

102 Nova Scotia, which usually occur at depths of 1-5 m (Schmidt, Romanuk \& Lotze, 2011; Cullain

103 et al., 2017) with optimal growing temperatures ranging from 10-25 ${ }^{\circ} \mathrm{C}$ (DFO 2009a). In general,

104 surficial sediments in Port Mouton and Port Joli Bay are a mix of muddy, sandy and gravelly

105 sand, but in sheltered areas muddy sands predominate (Table 2; Piper et al,1986).

106 A finfish farm has been operating in Port Mouton Bay since 1995. The current fish farm lease

107 (4354'54.11” N; -6448'43.62” W) near Spectacle Island (Fig. 1) occupies an area of 8 hectares

108 (ha) and the sea cages occupy $\sim 0.58$ ha of the lease area (McIver et al., 2018). The fish farm was

109 initially stocked with rainbow trout (Oncorhynchus mykiss) until 2000, followed by Atlantic

110 salmon (Salmo salar) until 2009, fallowed from 2010-2012, stocked with rainbow trout in 2012-

111 2014. The farm lease has been re-licensed for Atlantic salmon and rainbow trout from March

1122015 to March 2020 (NSDFA, 2017). Information on production at the farm site is deemed

113 proprietary, however it has been estimated at $760 \mathrm{mt}$ annually for 2012-2014, with an estimated

$11430 \mathrm{mt}$ of dissolved inorganic nitrogen being released from the farm every year (McIver et al.,

115 2018). Environmental monitoring at the fish farm indicated that in 2014, one year prior to our

116 sampling, mean sediment sulphides, an indicator or organic enrichment, were $4000 \mu \mathrm{M}$ (NSDFA

117 2014). Sediment enriched with organic waste from fish farms and having sulphide values $>3000$

$118 \mathrm{uM}$ are classified as hypoxic indicating redox values $<-100 \mathrm{mV}$ and poor macrofaunal diversity

119 (Hargrave 2010). In general, Port Mouton Bay is ice-free in the winter, but ice conditions do

120 occur with the most recent event in 2015, five months prior to our sampling. This super chill

121 event killed almost all the fish and the farm has not been restocked. Therefore, there were no fish

122 in the farm cages when we collected our data in July 2015, which may have reduced the potential

123 for immediate short-term impacts being observed, but not the long-term impacts. 


\section{Sampling design and data collection}

126 In accordance with the published literature on the impacts of fish farms on Mediterranean

127 seagrass beds (Table 1), the aims of our study were to test for differences in 1) environmental

128 variables, including sediment organic content, microphytobenthos chlorophyll- $a$ concentration,

129 percent cover of epiphytic and benthic annual algae and epiphytic fauna, 2) eelgrass tissue

130 variables, including \% nitrogen content and stable isotope ratios of $\delta^{15} \mathrm{~N}$ and $\delta^{13} \mathrm{C}, 3$ ) eelgrass

131 plant and canopy structure, including canopy height, shoot density, percent cover and biomass,

132 and 4) macroinfauna abundance, biomass, species richness and community composition between

133 study sites with increasing distance from the finfish farm in Port Mouton Bay and a reference site

134 in adjacent Port Joli (PJ) Bay (Fig. 1, Table 2). We also compared our result to published data

135 from seven other Nova Scotia sites (NS) without fish farms along the Atlantic Coast (Fig. 1,

136 Table 2; Cullain et al., 2017) to check whether our reference site PJ is representative of other NS

137 sites. Finally, we also aimed to 5) link the observed differences in macroinfaunal communities to

138 the environmental, eelgrass tissue and canopy variables using multivariate distance matrices.

139 Initially, five sampling sites were identified in Port Mouton Bay (Fig. 1). In 2014, the Jackie's

140 Island and Port Mouton Island sites (Fig. 1, historical eelgrass beds) had healthy eelgrass beds

141 (Lee, 2014) that were still visible during our pilot survey (April 2015); however, by July 2015,

142 these sites were highly degraded and had largely disappeared and therefore rejected as sampling

143 sites. The three remaining sites were at varying distances from the finfish farm (Fig. 1, Table 2):

144 an eelgrass bed closest $(\sim 300 \mathrm{~m})$ to the fish farm at Spectacle Island (SI), an eelgrass bed $\sim 700 \mathrm{~m}$

145 from the fish farm and close to Carters Beach (CB), and an eelgrass bed near an Old Wharf

146 (OW) 3000 $\mathrm{m}$ from the fish farm. A reference site ( $>10 \mathrm{~km}$ from the farm) was selected in

147 adjacent Port Joli Bay (PJ) with similar physical and biogeographical conditions (Fig. 1, Table

148 2). Port Joli Bay is bounded by protected land (Kejimkujik National Park and Thomas Raddall

149 Provincial Park) which restricts human development and nutrient loading in the area (Nagel et

150 al., 2018). The seven other NS sites were spread on the southern and eastern shore of Nova

151 Scotia (Fig.1, Table 2), were generally comparable to the characteristics at the four study sites

152 described above, and had been surveyed in 2013 with the same methodology and timing (mid

153 July to early August) as our study (Cullain et al., 2017), except for 3 sites (SM, ST and CR)

154 where some environmental (microphytobenthos, sediment organic content) and eelgrass tissue 
155 variables $\left(\% \mathrm{~N}, \delta^{13} \mathrm{C}, \delta^{15} \mathrm{~N}\right)$ had not been collected. These seven other NS sites had no fish farm

156 or other major point source of pollution close the respective sampling sites (Cullain et al., 2017).

157 All sites were in relatively sheltered, shallow, soft-sediment areas (Table 2; Fig 1) with

158 eelgrass as the dominant macrophyte (continuous beds $>50 \mathrm{~m}$ ). Field surveys were conducted in

159 Port Mouton Bay and Port Joli Bay from July 14-21, 2015. At each site, two 50 x 4 m transects

160 were laid approximately $6 \mathrm{~m}$ apart parallel to the shore inside the eelgrass bed $\geq 10 \mathrm{~m}$ from the

161 vegetation-bare substrate interface. All sampling was conducted during high tide at the same 6

162 locations; 0, 30, and $50 \mathrm{~m}$ along the shoreward transect and 5, 25, and $45 \mathrm{~m}$ along the seaward

163 transect. Using SCUBA, eelgrass canopy structure (shoot density, canopy height, percent cover)

164 and the percent cover of all epiphytic and benthic macroalgae and epiphytic fauna were assessed

165 using quadrat sampling $(0.5 \times 0.5 \mathrm{~m})$. A $0.25 \times 0.25 \mathrm{~m}$ inset was used to count the number of

166 shoots and measure canopy height in the centre of the quadrat by holding the zero end of a

167 measuring tape against the substrate and extending it to the average height of the $80 \%$ of the

168 plants (Duarte \& Kirkman, 2001). The percent cover measures were estimated to the nearest 2\%

169 and we considered both sides of all eelgrass blades in the quadrat as habitable space for epiphytic

170 cover. Therefore, if both sides of all the blades in the quadrat were covered with epiphytes, this

171 would represent $100 \%$ cover. For the macroalgae, we separated all species used as common

172 indicators of eutrophication for further analysis, including all annual green and brown algae

173 (Ulva intestinalis, Spongomorpha sp., Ectocarpus siliculosus, Pilayella littoralis, Sphaerotrichia

174 divaricata, Worm \& Lotze 2006; Schmidt et al., 2012). If species needed further identification,

175 they were bagged and examined under a field dissecting microscope. Similarly, from the

176 epiphytic fauna, we separated species identified as potential indicators of environmental

177 disturbance such as increased turbidity and organic loading (Ben Brahim et al., 2014) which in

178 our surveys were primarily hydroids (Campanularia sp.). Temperature and depth were recorded

179 on SCUBA dive computers.

180 Seagrass biomass as well as the abundance of sediment macroinfauna were collected using

181 sediment cores ( $0.2 \mathrm{~m}$ diameter; $0.2 \mathrm{~m}$ deep) at each of the 6 sampling locations along the

182 transects at each site. First, we examined the core to check whether we could observe a redox

183 potential discontinuity (RPD) layer, any black or anoxic sediment and sulfur smell. Next, all

184 aboveground ( $\mathrm{AG}$ ) and belowground (BG) eelgrass tissue was removed, rinsed in a $500 \mu \mathrm{m}$ sieve

185 to capture any fauna, bagged and kept on ice. Sediment type in each core was recorded (e.g. 
186 sand, mud), and the presence of any sulfur smell indicating hypoxia or anoxia. The remainder of

187 the core contents were sieved $(500 \mu \mathrm{m})$ on site and all macroinfauna species were identified to

188 the lowest possible taxon. If organisms needed further identification, they were kept on ice and

189 brought back to the laboratory and examined under a dissecting microscope. Individuals of each

190 species were counted (abundance $\mathrm{m}^{-2}$ ) and wet weighed (biomass WW $\mathrm{g} \mathrm{m}^{-2}$ ). In the laboratory,

191 the eelgrass blades (AG) and roots and rhizomes (BG) were rinsed again and all epiphytes were

192 carefully scraped off the blades. AG and BG tissue was then weighed (WW, $\mathrm{g} \mathrm{m}^{-2}$ ) prior to

193 drying in an oven at $60^{\circ} \mathrm{C}$ for 48 hours and weighed again for dry weight (DW $\left.\mathrm{g} \mathrm{m}^{-2}\right)$. Once dry,

194 the AG and BG tissues were homogenized separately and a well-mixed $50 \mathrm{mg}$ subsample of each

195 were sent to the University of California Davis Stable Isotope facility to analyze the tissue

196 nitrogen $(\% \mathrm{~N})$ content as well as the carbon $\left(\delta^{13} \mathrm{C}\right)$ and nitrogen $\left(\delta^{15} \mathrm{~N}\right)$ stable isotopes.

197 Microphytobenthos (MPB) and sediment organic content (SOC) were collected using $60 \mathrm{ml}$

198 syringe cores (2.6 cm diameter; $2 \mathrm{~cm}$ and $5 \mathrm{~cm}$ depth, respectively). At each of the 6 sampling

199 locations, two samples were collected for SOC (volume of sample $\sim 8.83 \mathrm{~mL}$ ) and three for MPB

200 (volume of sample $\sim 3.53 \mathrm{~mL}$ ). Both SOC samples were placed in a plastic bag and frozen until

201 processed whereas each set of three MPB samples were combined on site, placed in plastic

202 cryovials and stored in liquid nitrogen while in the field and in a freezer $\left(-20^{\circ} \mathrm{C}\right)$ until analysis in

203 the laboratory. In the laboratory, SOC samples were processed according to Luczak, Janquin \&

204 Kupka (1997). All MPB samples were processed in a darkened room. Frozen sediment samples

205 were placed in labeled glass scintillation vials with $10 \mathrm{~mL}$ of $90 \%$ acetone, vortexed for 1 minute

206 and then placed back in the freezer to be digested for 24 hours. The following day, samples were

207 vortexed for one minute, placed in falcon tubes and centrifuged for 30 minutes at $3250 \mathrm{rpm}$ (T.

208 Whitsit, Dalhousie University, pers. comm). The supernatant was subsequently pipetted into

209 clean scintillation vials and measured in a Turner Designs 10005R fluorometer to determine

210 chlorophyll- $a$ concentrations.

211

\section{Data analysis}

213 Samples from the 6 cores at all sites were grouped according to their site designation (SI, OW,

$214 \mathrm{CB}, \mathrm{PJ}$ ) except for the 7 other sites that were grouped into NS as their site designation and

215 included in the statistical analyses. As such, we had 1 fixed factor (site) with 5 levels (SI, OW,

$216 \mathrm{CB}, \mathrm{PJ}$ and NS). We used multivariate permutational analysis of variance (PERMANOVA) to 
217 assess the effect of site on the Euclidean distance matrix of each non-independent pair of canopy 218 and environmental variables. If statistically significant $(p \leq 0.05)$ differences were found in the 219 paired variables, univariate PERMANOVA was used to assess the effect of site on each of the 220 individual environmental and eelgrass parameters followed by post-hoc pairwise tests between 221 sites if there was a significant main effect. We also considered significance levels of $p \leq 0.1$ if 222 differences were ecologically relevant with regard to observed effects in the published literature 223 (Table1; EFSA 2011). Similarly, univariate PERMANOVA and pairwise tests were used for the 224 independent environmental variables (SOC, MPB) and arcsine transformed zero-adjusted Bray225 Curtis similarity matrix for each of annual algae, hydroids and eelgrass $\%$ cover. Zero-adjusting 226 dampens the fluctuations of the metric for near-blank samples in an analogous way to the 227 addition of a constant to the log transformation (Clarke and Gorley, 2015).

228 To determine differences in macroinfauna community composition between sites, multivariate 229 PERMANOVA was used on the zero adjusted Bray-Curtis similarity matrix of abundance 230 (density) and biomass separately both with and without the inclusion of the NS sites. Abundance 231 and biomass data were square-root transformed in order to down-weight the influence of highly 232 abundant or large species (Clarke \& Gorley, 2015). If a significant effect of site was detected, we 233 used post-hoc pairwise tests to determine which sites were significantly different from each other 234 and group average cluster analysis using the centroids of each site to visualize the community 235 data. Univariate PERMANOVA on the Euclidean distance matrix of species richness as well as 236 the square-root transformed zero-adjusted Bray-Curtis similarity matrix of each of total 237 macroinfauna abundance and biomass was used to identify differences in individual summary 238 measures between sites.

239 To focus in on the potential effects of the fish farm, we excluded the NS sites when using 240 abundance-biomass comparison (ABC) curves, SIMPER and BIOENV analyses. We used ABC 241 curves of the log species rank ( $\mathrm{x}$-axis) and the cumulative percent dominance (y-axis) to compare 242 the $k$-dominance curves for macroinfauna abundance and biomass at each site (Warwick, 1986). 243 In unpolluted sites, the biomass curve will be above the abundance curve, in moderately polluted 244 areas the two curves will closely coincide, and in grossly polluted sites the abundance curve will 245 be above the biomass curve (Warwick 1986, Warwick et al., 1987). This method expands on the 246 theory by Pearson \& Rosenberg (1978) where unpolluted sites will have less but larger 
247 individuals, but will shift to higher abundances of small opportunistic species as pollution level 248 increases.

249 To determine which species contributed most consistently $(>10 \%)$ to the differences in the 250 infauna assemblages between sites near the fish farm, we used similarity percentages (SIMPER) 251 analysis (Anderson et al., 2008). BIOENV was used to link the overall response of the 252 macroinfauna community to different environmental and eelgrass variables. Prior to these 253 analyses, we examined the correlations among all environmental (SOC, MPB, annual algae, 254 hydroids), eelgrass tissue ( $\mathrm{AG}$ and $\mathrm{BG}$ tissue $\% \mathrm{~N}, \mathrm{AG}$ and $\mathrm{BG} \delta^{13} \mathrm{C}$ and $\delta^{15} \mathrm{~N}$ ) and eelgrass 255 canopy variables (shoot density, canopy height, percent cover, AG and BG biomass) and those 256 with high correlation $(\geq 0.7)$ were never included in the same analysis. If variables were equally 257 correlated (e.g. AG and BG biomass), we chose to include the variable most relevant for infauna 258 (e.g. BG biomass). Therefore, four environmental (SOC, MPB, annual algae, hydroids), three 259 eelgrass tissue ( $\mathrm{BG} \% \mathrm{~N}, \mathrm{BG} \delta^{13} \mathrm{C}, \mathrm{BG} \delta^{15} \mathrm{~N}$ ), and four eelgrass canopy (shoot density, canopy 260 height, percent cover, BG eelgrass biomass) variables were used in the analyses. BIOENV 261 provides a non-parametric index rho (ranging from 0 to 1 ) that indicates how closely different 262 combinations of environment and eelgrass canopy variables explain the multivariate pattern of 263 the macroinfauna community based on the abundance and biomass data and individual SIMPER 264 species. We then used a permutation test to determine the significance level of the sample 265 statistic (rho).

Finally, to combine all variables, we ran a non-metric MDS overlaid with cluster analysis using a normalized Euclidean distance matrix of all environmental, eelgrass tissue and eelgrass canopy variables, as well as macroinfauna total abundance, total biomass and species richness to explore how the sites in Port Mouton Bay and Port Joli Bay cluster relative to the other sites in Nova Scotia. All PERMANOVA, MDS, cluster, ABC, SIMPER and BIOENV analyses were carried out using PRIMER (version 6.1.11) with PERMANOVA+ (version 1.0.1, PRIMER-E,

272 Plymouth).

273

274 RESULTS

275 Environmental, eelgrass tissue and eelgrass canopy variables

276 Bottom temperature ranged from $12-15^{\circ} \mathrm{C}$ between the four sites and sampling depth ranged

277 from 1.7-2.9 m (Table 1). Sediment organic content differed between sites (Table 3), with SI, 
278 OW and NS having statistically significantly higher organic content than CB and PJ (Fig. 2a).

279 Microphytobenthos did not differ significantly between sites (Table 3), although higher mean

280 values were observed at the three Port Mouton Bay sites compared to PJ and NS (Fig. 2b). There

281 were significant site effects on the cover of annual algae and epiphytic hydroids (Table 3), with

282 CB having the highest cover of annual algae and SI the highest cover of hydroids (Fig. 2c).

283 These observed patterns in environmental variables are in line with those reported in the

284 literature (Table 1).

285 For above- (AG) and belowground (BG) tissue nitrogen $(\% \mathrm{~N})$, no statistically significant ( $\mathrm{p}>$ 286 0.05) but ecologically relevant differences were found (Table 3), with the three Port Mouton sites 287 having higher mean $\mathrm{AG} \% \mathrm{~N}$ compared to $\mathrm{PJ}$ and $\mathrm{NS}$ sites (Fig. 3a). Both $\mathrm{AG}$ and $\mathrm{BG}$ carbon $288\left(\delta^{13} \mathrm{C}\right)$ and nitrogen $\left(\delta^{15} \mathrm{~N}\right)$ stable-isotope ratios significantly differed between sites (Table 3 ), 289 with $\mathrm{CB}$ having higher $\mathrm{AG} \delta^{13} \mathrm{C}$ and $\mathrm{CB}$ and SI having higher $\mathrm{BG} \delta^{13} \mathrm{C}$ than the other sites (Fig. 290 3b). For both AG and BG $\delta^{15} \mathrm{~N}$, SI and OW had lower values than CB, PJ and NS (Fig. 3c). The

291 observed patterns in eelgrass tissue variables except $\delta^{15} \mathrm{~N}$ are in line with the published literature 292 (Table 1).

293 Multivariate PERMANOVA detected no statistically significant differences for eelgrass shoot 294 density and canopy height across sites (Table 3; Fig. 4a, b), but there was a tendency for lower 295 shoot density at the sites closer to the fish farm (SI and CB) than the other sites including NS 296 (Fig. 4a). Eelgrass cover and both AG and BG biomass decreased at sites closer to the fish farm

297 (Fig. 4c, d), which was significant for eelgrass cover (Table 3). Despite the significant

298 multivariate site effect on $\mathrm{AG}$ and BG biomass, the univariate tests were only $\mathrm{p}<0.1$ and

299 showed that SI and CB had lower AG and BG biomass than PJ and NS. These observed patterns

300 on eelgrass canopy variables are in line with the published literature (Table 1).

301

302

Macroinfauna community

303

304

A total of 36 macroinfauna genera were identified across all sites, 26 of which were identified to the species level. Univariate PERMANOVA detected a difference in the summary measures of 305 total abundance (pseudo- $\mathrm{F}_{4,60}=2.15, \mathrm{p}=0.056$ ) and total biomass (pseudo- $\mathrm{F}_{4,60}=2.68, \mathrm{p}=$

306 0.023 ), but not for species richness ( $p$ seudo- $F_{4,60}=0.49, p=0.73$ ) of macroinfauna between sites (Fig. 5). Both the abundance and biomass of CB were significantly lower than OW and NS but the variability in the other sites precluded significant differences (Fig 5a, b). Overall the three 
309 sites in Port Mouton Bay tended to have lower macroinfaunal biomass compared to PJ and NS 310 (Fig. 5b).

311 The ABC curves for cumulative dominance for the sites in Port Mouton and Port Joli showed 312 that macroinfauna biomass was distinctly above the abundance curve for both CB and PJ (Fig. $3136 \mathrm{~b}, \mathrm{~d})$, indicating unpolluted conditions. The biomass and abundance curves for SI approached 314 each other but did not overlap (Fig. 6a), suggesting that this site is approaching moderately 315 polluted conditions. The OW site was the only site where the abundance curve lay above the 316 biomass curve (Fig. 6c), indicating polluted conditions.

317 Macroinfauna community composition based on both abundance and biomass did differ 318 significantly between sites (multivariate PERMANOVA: $p s e u d o-F_{5,60}=2.0, p=0.002$ and 319 pseudo- $\mathrm{F}_{4,60}=1.91, \mathrm{p}=0.001$; respectively). Cluster analysis of centroids based on infauna 320 abundance data (Fig. 7a) showed a clustering of SI and OW, which were the more polluted sites 321 as identified by the ABC curves, while cluster analysis of infauna biomass data (Fig. 7b) showed 322 a clustering of SI and CB, the two sites closest to the fish farm. In both cases, PJ clustered with 323 NS indicating that it is a representative control site. When we excluded the other NS sites to 324 more closely examine the effects of the fish farm, the PERMANOVA and cluster analyses based 325 on abundance and biomass yielded similar results.

326 The main species identified by SIMPER contributing $>10 \%$ of differences in abundance and 327 biomass between sites included three polychaetes: Clymenella torquata, Capitella capitata, and 328 Nephtys sp. with the addition of Amphitrite sp. for biomass. However, the contribution of each 329 species to the community differed when considering abundance or biomass, respectively (Table

330 4). C. torquata dominated the community in abundance across all sites except $\mathrm{CB}$, and in 331 biomass except in PJ, where Amphitrite sp. was the dominant species (Table 4). The 332 opportunistic polychaete $C$. capitata only occurred at the two more polluted sites in Port Mouton 333 Bay (SI, OW), with the highest abundance and biomass closest to the fish farm (Table 4). The 334 polychaete Nephthys sp. also showed higher abundance at the two more polluted sites (SI, OW). 335 In turn, Amphitrite sp. as well as Ophelia sp. only occurred at the reference site PJ, whereas the 336 bivalves Cerastoderma pinnulatum and Tellina agilis were most abundant at CB (Table 4).

\section{Linking the environment to the macroinfauna community}


339 BIOENV was used to determine any associations between the Euclidean distance of

340 environmental, eelgrass tissue, and eelgrass bed structure variables (SOC, MPB, annual algae,

341 hydroids, $\mathrm{BG} \% \mathrm{~N}, \mathrm{BG} \delta^{15} \mathrm{~N}, \mathrm{BG} \delta^{13} \mathrm{C}$, eelgrass shoot density, canopy height, percent cover, and

342 BG biomass) and the Bray-Curtis similarity matrix of macroinfauna community structure (Table

343 5). The community assemblage based on abundance data was most correlated to $B G \% N$, BG

$344 \delta^{13} \mathrm{C}$ and the percent cover of annual algae $(\% \mathrm{~A})$, and the assemblage based on biomass data to

345 BG eelgrass biomass, $\mathrm{BG} \% \mathrm{~N}$ and $\mathrm{BG} \delta^{13} \mathrm{C}$ (Table 5). Both the abundance and biomass of $C$.

346 capitata were most correlated to the percent cover of hydroids $(\% \mathrm{H})$, while the next best

347 correlations also included SOC and MPB. In contrast, the other species were more correlated

348 with eelgrass bed structure, with BG eelgrass biomass being the most important (Table 5).

349 Combining all environmental, eelgrass tissue and eelgrass bed structure variables as well as

350 total macroinfauna abundance, biomass and species richness in a nMDS and cluster analysis

351 revealed a distinct cluster of the reference site (PJ) and NS, and another cluster of the more

352 polluted sites, SI and OW (Fig. 7c).

353

354 DISCUSSION

355 Our study quantitatively assessed the potential impacts of finfish aquaculture on eelgrass bed

356 structure and associated macroinfaunal communities in Atlantic Canada and framed these results

357 in a broader context of fish farm impacts on seagrass beds elsewhere. Our results suggest higher

358 nutrient and organic enrichment, higher algae and epiphyte loads, lower eelgrass cover and

359 biomass, and lower macroinfauna biomass closer to the fish farm. Moreover, the macroinfauna

360 community showed significantly altered species composition. Importantly, the opportunistic

361 polychaete Capitella capitata, a known indicator of polluted conditions, specifically organic

362 enrichment (Pearson \& Rosenberg, 1978) reached its highest abundance close to the fish farm at

363 Spectacle Island (SI), and also occurred at an Old Wharf site (OW) with a history of pollution.

364 This was strongly correlated with higher loads of epiphytic suspension-feeding hydroids and

365 higher sediment organic content pointing to organic enrichment at these sites. The combined

366 assessment of multiple eelgrass tissue, canopy and environmental variables was important in

367 evaluating ecological changes, particularly differences between impacted and unimpacted

368 ecosystems. Overall, the observed patterns at our study sites are in line with published results on

369 the impacts of fish farms on Mediterranean seagrass beds (Table 1). We discuss possible metrics 
370 for assessing and monitoring local and broader-scale impacts of nutrient and organic enrichment

371 from fish farms on eelgrass ecosystems.

372

373 Environmental variables

374 Several physical and biogeochemical factors are known to influence eelgrass growth and

375 survival, including wave exposure, sediment type and water quality (Frederiksen et al., 2004;

376 Vandermeulen, 2005). While all our study sites were in relatively sheltered areas with similar

377 wave exposure, SI and OW sites were the most sheltered, with SI nestled behind an island and

378 OW positioned in the inner most part of the bay. Current speeds in Port Mouton Bay are

379 generally low (2-3 $\mathrm{cm} \mathrm{sec}^{-1}$, Gregory et al., 1993) and flushing times long (114 hours, Nagel et

380 al., 2018), which could lead to higher sedimentation rates compared to adjacent Port Joli (PJ)

381 Bay, which has faster flushing times (53 hours, Nagel et al., 2018). We found the highest amount

382 of organic matter in sediments closest to the fish farm at SI, followed by OW, while Carters

383 Beach (CB) inside Port Mouton Bay and the PJ reference site had much lower sediment organic

384 content. In contrast, the other NS sites also had relatively high organic content. Both SI and OW

385 have been affected by long-term anthropogenic activities. The (abandoned) Old Wharf is in an

386 area of higher coastal development with some direct discharge of domestic sewage and a former

387 fish processing plant. The fish farm at SI has been in operation, on and off, since 1995. Although

388 no redox potential discontinuity (RPD) layer was observed at any of the sites during sampling,

389 strong sulfur smell and dark black sediments were observed while sampling at SI and OW.

390 A potential early indicator of nutrient enrichment is the increased concentration of

391 microphytobenthos, composed primarily of diatoms and cyanobacteria (Lever \& Valiela, 2005).

392 Although not statistically significant, we observed higher mean microphytobenthos chlorophyll- $a$

393 concentrations at sites within Port Mouton Bay compared to the reference PJ and other NS sites,

394 in line with expected patterns from the published literature (Table 1). The enhanced

395 microphytobenthos productivity in Port Mouton Bay may be a result of the overall higher

396 nutrient loading from greater human development in the watershed and the finfish farm in the

397 bay (McIver et al., 2018) compared to the more protected and less developed watershed in Port

398 Joli Bay with much lower nutrient loading (Nagel et al., 2018). Under enhanced nutrient loading,

399 increased microphytobenthos concentration can shift sediment conditions from being autotrophic

400 to net heterotrophic, where sediments become increasingly hypoxic or anoxic, sulphides 
401 accumulate, and denitrification and mineralization are enhanced (Meyer-Reil \& Köster, 2000;

402 Sundbäck et al., 2004; Hardison et al., 2013). Seagrasses can grow in low sediment oxygen

403 conditions and some species such as Z. marina can tolerate higher levels of porewater sulphides

404 (Hasler-Sheetal \& Holmer 2015); however, the combination of hypoxia and high sulphides (100-

$4051000 \mu \mathrm{M})$ has been shown to affect $Z$. marina growth and survival, specifically reducing

406 photosynthetic activity, decreasing biomass, and increasing decay in the meristematic region of

407 the plant (Holmer \& Bondgaard 2001).

408 Eelgrass tissue nitrogen content and stable-isotope ratios are commonly used to trace the 409 amount and source of nitrogen, respectively, within seagrass ecosystems (Hemminga \& Duarte,

410 2000; Dolenec et al., 2006; Ruiz, Marco-Méndez \& Sánchez-Lizaso, 2010). The higher mean

411 tissue nitrogen content within Port Mouton Bay compared to the reference PJ and other NS sites

412 also point to higher nutrient availability within Port Mouton Bay, possibly due to higher nutrient

413 loading (Nagel et al., 2018). However, this seemed to be distributed throughout the bay, as there

414 was no elevated tissue content at the SI site closest to the fish farm. We also did not find elevated

415 stable isotope $\delta^{15} \mathrm{~N}$ values at the fish farm site. Generally, wastewater from human or animal

416 waste has a higher $\delta^{15} \mathrm{~N}$ signature (ratio of ${ }^{15} \mathrm{~N} /{ }^{14} \mathrm{~N}$ ) of $8-10 \%$ up to $20 \%$ (Lepoint, Dauby \&

417 Gobert, 2004; Schubert et al., 2013), and fish farm waste (feces, mucus, pellets) has $\delta^{15} \mathrm{~N}$ values

418 of 6.5-10.5\%o (Dolonec et al., 2006; Sarà et al., 2006; Ruiz, Marco-Méndez \& Sánchez-Lizaso,

419 2010). Several studies have found significantly elevated $\delta^{15} \mathrm{~N}$ at varying distances $(250-900 \mathrm{~m})$

420 up to >1000 m from fish farms (Table 1; Holmer et al., 2007; Ruiz, Marco-Méndez \& Sánchez-

421 Lizaso, 2010; García-Sanz et al., 2011). These values depend on hydrographical characteristics

422 (e.g. depth, current speeds) at and around the farm site, the scale of farm production and feeding 423 efficiencies (Sarà et al., 2006; Holmer et al., 2007). At our sites, $\delta^{15} \mathrm{~N}$ values of 4-6.5\%o were 424 within the range of natural variation in seagrass ecosystems (Hemminga \& Mateo, 1996;

425 Lepoint, Dauby \& Gobert, 2004) and comparable to values reported in other Atlantic Canadian

426 bays (McIver, Milewski \& Lotze, 2015). This may be explained by the fact that production at the 427 fish farm ceased 5 months prior to our sampling in July due to a super chill event that killed all 428 the fish, allowing time for the $\delta^{15} \mathrm{~N}$ in the eelgrass tissue to be adequately used or cycled within 429 the system. This may also explain why we did not measure enhanced tissue nitrogen content 430 directly at the Spectacle Island site, but rather throughout Port Mouton Bay. 
Stable carbon isotope ratios $\left(\delta^{13} \mathrm{C}\right)$ are used for studying the source and fate of organic carbon

432

433

434

435

436

437

438

439

440

441

442

443

444

445

446

447

448

449

450

451

452

453

454

455

456

457

458

459

460

461

in ecosystems and food webs. Under increased nutrient and organic loading which, among other effects, increases sediment organic content and decreases light conditions, the balance in carbon utilization in seagrasses shifts from inorganic carbon fixation (photosynthesis) toward belowground consumption of organic carbon (respiration) (Holmer \& Bondgaard, 2001; Holmer et al., 2004). A more negative isotopic signature represents the input of ${ }^{13} \mathrm{C}$-depleted carbon from the decomposition of organic material (Hemminga \& Mateo, 1996). We found less negative $\delta^{13} \mathrm{C}$ further away from the finfish farm particularly in belowground roots and rhizomes. Similar patterns of less negative $\delta^{13} \mathrm{C}$ further away from the source have been observed in other seagrass beds which receive organic material from fish farms (Vizzini \& Mazzola, 2014; Holmer et al., 2004) or land run-off (Hemminga \& Mateo, 1996; Hemminga \& Duarte, 2000). Thus, while the nitrogen signal may have disappeared due to the fish farm not being stocked at the time of sampling, the organic carbon signal was still visible.

Changes in seagrass physiology (e.g. tissue nutrient content and $\delta^{15} \mathrm{~N}$ ) in response to changes in nutrient supply or environmental quality (e.g. increased turbidity, decreased light intensity) occurs more quickly (days and weeks) than changes to morphology (e.g. biomass, shoot density) (Grice et al., 1996; Longstaff \& Dennison,1999). Under high sediment sulphide conditions (commonly associated with organic loading, Pearson \& Rosenberg, 1978), however, both physiological (non-structural carbohydrates and $\delta^{13} \mathrm{C}$ isotope signatures) and morphological (dead leaves and rot in the meristematic region) have been observed within 3 weeks (Holmer \& Bondgaard, 2001). Physiological seagrass measures, therefore, can be good early indicators of change (both deterioration or recovery) and can be used to detect changes to specific stressors (Roca et al., 2016).

\section{Eelgrass bed structure}

Frequent responses of seagrasses to increased nutrient and organic loading are decreases in shoot density, biomass and cover, and increases in canopy height (Short et al., 2011; Schmidt et al., 2012). Our results suggest lower mean shoot density, cover, and biomass closer to the fish farm compared to the reference PJ and other NS sites, similar to other studies on the impacts of fish farm effluent on seagrasses (Table 1; Pergent-Martini et al., 2006). A synthesis of the effects of Mediterranean fish farms reported that the most important process affecting Posidonia oceanica 
462 was the sedimentation of organic material (Holmer et al., 2008). Estimated dispersion distances

463 from fish farms are variable, but the furthest distances of organic-enriched material has not

464 exceeded 1000 m (Sarà et al., 2004; Holmer et al., 2007). For the Mediterranean, Díaz-Almela et

465 al. (2008) proposed a rate of $1.5 \mathrm{~g}$ organic matter $\mathrm{m}^{-2} \mathrm{~d}^{-1}$ as a threshold to protect $P$. oceanica

466 from the impacts of fish farms. Although we did not measure sedimentation rates, the

467 development of a comparable threshold value for eelgrass habitat in Atlantic Canada would be a

468 valuable tool for protecting eelgrass from the impacts of finfish aquaculture as well as other

469 anthropogenic activities.

470

471

\section{Macroinfauna}

472 The ABC curves allowed us to use the total macroinfauna abundance and biomass to examine

473 the sites based on a pollution gradient (Warwick, 1986). Our results indicate that OW is

474 considered the most polluted site, followed by SI, while the reference site PJ can be considered

475 unpolluted. The location of OW may explain its polluted status as this site has a decades-long,

476 cumulative history of coastal development including direct sewage outflow and a former fish

477 processing plant which is no longer in operation. The fish farm near SI, on the other hand, has

478 been in operation on and off for 19 (1995-2015) years while the reference site PJ has no

479 industrial development. SI, however, did show the two ABC curves approaching each other,

480 indicating that the site may be transitioning to/from a polluted state (Warwick, 1986). Since our

481 study sites were only sampled during one time period, it would be important and valuable from a

482 management perspective to monitor changes in these ABC curves seasonally and over the years.

483 Summary measures of the macroinfauna community suggested lower total abundance and

484 biomass at CB, and potentially lower biomass at the other Port Mouton Bay sites compared to

485 the reference PJ and other NS sites but with high variability. This is likely due to the significant

486 changes in species composition, with some species increasing and others decreasing (Table 4).

487 Thereby, two polychaete species, C. capitata and C. torquata, were the main contributors to the

488 differences among sites based on both abundance or biomass. The higher abundance and biomass

489 of C. capitata at SI, followed by OW, is not surprising as C. capitata has long been associated

490 with sediment organic enrichment from human activities (e.g. sewage, seafood, and wood-

491 processing facilities) including finfish aquaculture (Mazzola et al., 2000; Holmer, Wildish \&

492 Hargrave, 2005; Martinez-Garcia et a., 2013). 
493 In their study on the effects of fish farming on soft-bottom polychaete assemblages, Martinez-

494 Garcia et al. (2013) reported that tolerance to higher total dissolved sulphides, silt and clay

495 fractions, and sediment stable isotope nitrogen signatures were the main sediment factors that

496 distinguished the occurrence of polychaete families such as Capitellidae compared to families

497 that are more sensitive (meaning a decrease in abundance) to fish farm pollution such as

498 Maldanidae and Nephtyidae, although species in these families were also found in low impact

499 areas. These latter families include two polychaete species, Clymenella sp. and Nephtys sp.

500 respectively, found in variable abundance at our study sites. Nephtys sp. abundance has been

501 found to fluctuate along a stress or pollution gradient in a bimodal pattern (Pearson et al.1983).

502 The lowest numbers were found next to pollutant sources, followed by higher numbers $\sim 0.5 \mathrm{~km}$

503 further out, then a drop in numbers $2 \mathrm{~km}$ away and finally an increase and stabilization $\sim 6 \mathrm{~km}$

504 away (Pearson, Gray \& Johannessen, 1983). In our study, we did not discern this pattern for

505 Nephtys sp. as our sampling design was not on the same spatial or temporal scale as reported in

506 Pearson, Gray \& Johannessen (1983); however, we found higher number of Nephtys sp. at SI

$507(\sim 0.3 \mathrm{~km})$ followed by lower numbers at CB $(\sim 0.7 \mathrm{~km})$ (Table 4$)$. C. torquata is viewed as an

508 important macroinfaunal species in Z. marina habitat because higher densities of these worms

509 (>192 worms $\mathrm{m}^{-2}$ ) are responsible for adding topographical relief to sediments which in turn is

510 more effective in trapping and burying $Z$. marina seeds and, hence, improving recruitment

511 (Luckenback \& Orth 1999). In our study C. torquata abundance was lowest at the sites closest to

512 the fish farm (SI and CB) suggesting a potential recruitment risk to the eelgrass beds in these

513 areas that should warrant further monitoring.

514 Other species in our data set such as Amphitrite sp. and Ophelia sp. were present only at our

515 reference site (PJ) and the mollusc Tellina agilis was present only at two sites closer to the fish

516 farm (SI and CB). The occurrence and distribution of these species is not readily explained

517 without further study. Apart from C. capitella, which is a widely used indicator of organic

518 enrichment, a potential other biological indicator to assess the impact of fish farm waste on

519 macroinfaunal in Z. marina habitat could include C. torquata.

520

521 Linking the environment/eelgrass structure to infauna community composition

522 Our results suggest that eelgrass bed structure, specifically belowground biomass, was a good

523 predictor of community and individual species abundance or biomass, but also shoot density and 
524 cover. Moreover, tissue nitrogen as an indicator of nutrient enrichment, $\delta^{13} \mathrm{C}$ as an indicator for

525 enhanced decomposition of organic material, and the cover of epiphytic and benthic annual

526 macroalgae $(\% \mathrm{~A})$ as a proxy for eutrophication could be linked to community composition based

527 on biomass or abundance. The correlation between macroinfauna composition and belowground

528 eelgrass biomass as well as detritus is well documented and has been linked to the role eelgrass

529 roots and rhizomes have in accumulating and stabilizing sediments which in turn provide habitat

530 and food to the associated detritivore-dominated infauna, releasing oxygen to the sediments and

531 providing protection from predators (Orth, Heck \& Montfrans, 1984; Lee, Bailey-Brock \&

532 McGurr, 2001, Boström, Jackson \& Simestad, 2006). Thereby, sediment grain size and stability

533 can covary with below ground biomass and shoot density to influence macroinfaunal

534 assemblages (Boström, Jackson \& Simestad, 2006). Terlizzi et al. (2010) reported that 98\%

535 of the changes in benthic faunal assemblages between control and fish farm impacted sites were

536 the result of changes in sediment features (sediment organic matter, grain size) and seagrass bed

537 structure (shoot density, rhizome matte compactness). As an important indicator species, the

538 abundance and biomass of $C$. capitata was most correlated to epiphytic suspension-feeding

539 hydroid cover $(\% \mathrm{H})$ as well as biogeochemical sediment conditions (sediment organic content,

540 microphytobenthos). Increases in epiphyte loads, both annual algae and suspension feeders, as

541 well as annual benthic macroalgae and microphytobenthos have been associated with increased

542 organic and nutrient loading from fish farms or other sources (Table 1; Lever \& Valiela, 2005;

543 Ben Brahim et al., 2014), thus reflecting enrichment conditions.

544 Our assessment of the correlation between macroinfaunal composition and environmental

545 factors may be confounded by the fact that the fish farm was not in operation at the time of our

546 sampling in July 2015. Finfish aquaculture operations are known to discharge significant

547 quantities of nutrient and organic waste to the surrounding environment. When in operation, the

548 Port Mouton Bay fish farm increased the annual total dissolved nitrogen load from human

549 sources to the entire bay by $14 \%$ or $30,400 \mathrm{~kg}$ (McIver et al., 2018), with the fish farm being the

550 single largest contributor of dissolved nitrogen to the bay after atmospheric deposition. The

551 release of particulate organic waste from fish farms can be significantly larger (10s-100s mt)

552 depending on the species raised, the scale of production and feed conversion efficiencies (Olsen,

553 Holmer \& Olsen, 2008). Impacts of fish farms on surrounding ecosystems can persist for several

554 months to years after production ceases (Delgado et al., 1999; Karakassis et al., 1999; Brooks, 
555 Stierns \& Backman, 2004; Pereira et al., 2004; Lin \& Bailey-Brock, 2008). As no waste was

556 being discharged from the farm site during our sampling season, our results likely represent the

557 long-term cumulative impacts of organic loading from the fish farm rather than a direct

558 immediate effect. Continued monitoring at the Spectacle Island and Carters Beach sites is highly

559 recommended to assess possible eelgrass habitat recovery and to provide managers with

560 scientific information on the development of monitoring metrics and impact thresholds that

561 would protect eelgrass from the adverse effects of finfish aquaculture.

562

563 Monitoring metrics for managing impacts

564 The sensitivity of seagrass habitats to environmental change and their link to sediments and the

565

566

567

568

569

570

571

572

573

574

575

576

577

578

579

580

581

582

583

584

585 water column make them ideal bioindicators of a wide range of anthropogenic stressors (e.g. shading, shoreline modification, nutrient and organic loading, climate change, ocean acidification) in coastal marine environments (Olivia et al., 2012; Roca et al., 2016). Consequently, many multi-metric indices and management tools incorporating seagrass physiological, individual, population and community-level traits have been developed to aid in monitoring general trends in ecosystem status, assessing environmental quality, and evaluating impacts of development projects (Romero et al., 2007, Oliva et al., 2012, García-Marín et al., 2013, Roca et al., 2016). An advantage to using multiple metrics is that some measures, such as tissue $\% \mathrm{~N}$ and $\delta^{15} \mathrm{~N}$, serve as an early warning because seagrasses respond relatively quickly (days to weeks) to nutrient disturbances while population-level measures, such as shoot density or biomass, reflect the impact of disturbances on longer time scales (months to years) (Romero et al., 2007; Roca et al., 2016). A single indicator does not allow for spatial and temporal (seasonal) fluctuations and potential sampling errors, account for different levels of organizational response (from physiological to community) or capture the lag-time in response of some metrics to either the degradation or recovery phase (Oliva et al., 2012).

Unlike Z. marina in Atlantic Canada, the impacts of netpen finfish farming on P. oceanica in the Mediterranean have been the subject of extensive research (Table 1) with the goal of identifying monitoring metrics and management tools (Holmer et al., 2008; Karakassis et al., 2013). As a result of these studies, specific recommendations, such as setting monitoring thresholds (e.g. $>1.5 \mathrm{~g}$ organic matter $\mathrm{m}^{-2}$ day $^{-2}$ results in seagrass decline; Diaz-Almeda et al., 2007) and siting restrictions (e.g. no fish farms $<800 \mathrm{~m}$ from the edge of seagrass beds; 
586 Karakassis et al., 2013) have been made to improve the regulatory schemes for protecting $P$.

587 oceanica beds from the impacts of finfish farms. While there are some physiological (e.g.

588 tolerance to sulphides; Hasler-Sheetal \& Holmer, 2015) and morphological (e.g. rhizome

589 diameter; Marbà \& Duarte, 1998) differences between seagrass species, the metrics identified by

590 research done elsewhere could be applied to eelgrass conservation and management in Atlantic

591 Canada. Currently, there are no specific monitoring thresholds or management tools in place to

592 protect eelgrass from the potential impacts of finfish aquaculture in Atlantic Canada. Based on

593 results from our study, from the Mediterranean (Table1) and the above discussion, we

594 recommend the development and application of the following metrics: sedimentation rates;

595 sediment sulphide and organic content; microphytobenthos concentration; prevalence of $C$.

596 capitata; epiphyte load and composition; eelgrass bed structure (shoot density, percent cover,

597 above- and belowground biomass); and tissue nitrogen content and isotopic signature. Our

598 selection of indicators is consistent with the key indicators identified for the response and

599 recovery of seagrasses to nutrient and organic loading in a recent global review and assessment

600 (Roca et al., 2016). As for siting fish farms near eelgrass habitat, we recommend that more

601 research needs to be done to define appropriate siting and zoning criteria for open netpen fish

602 farms (e.g., Vandermeulen, 2005). However, based on our study results and research done

603 elsewhere, we recommend a precautionary setback of $1000 \mathrm{~m}$ between eelgrass beds and open

604 netpen finfish farm to ensure the conservation and protection of this sensitive and ecologically

605 important habitat.

606

607 Conclusions

608 Within the last five to ten years, there have been growing concerns about the potential significant

609 spread and persistence of finfish aquaculture waste over large spatial areas (Price et al. 2015).

610 Our results reveal changes to eelgrass bed structure and associated macroinfauna communities

611 within Port Mouton Bay, particularly in closer proximity $(<1 \mathrm{~km})$ from the fish farm site. Given

612 the acknowledged status of eelgrass as an Ecologically Significant Species in Atlantic Canada

613 (DFO, 2009a), its key role in supporting productive and diverse species communities (Larkum et

614 al., 2006), and its sensitivity to anthropogenic disturbances, including finfish aquaculture

615 (Vandermeulen, 2005; DFO 2009a, 2012), management needs to include comprehensive eelgrass

616 habitat assessments and zoning criteria as part of the process for evaluating proposed finfish 
617 aquaculture operations. Effective indicators, with threshold values, need to be developed to

618 monitor existing operations to ensure that fish farms are operating in a sustainable manner.

619 Optimal indicators should integrate impacts over time and include multiple measures of eelgrass

620 canopy structure, tissue and environmental variables rather than single-event and individual

621 variables.

622

\section{Acknowledgements}

624 We thank K. Wilson, A. Dixon and T. Harington for support during the field surveys, A. Chan

625 for help in the lab, and M. Wong, M. Skinner, J. Grant, and S. Courtenay for helpful comments

626 and discussions. We would also like to thank the Friends of Port Mouton Bay Society for

627 providing their historical and contemporary knowledge of the Port Mouton area and marine

628 ecosystem.

629

630

\section{References}

631 Anderson M, Gorley R, Clarke K. 2008. PERMANOVA+ for PRIMER: A guide to software and 632 statistical methods. Plymouth: PRIMER-E Ltd.

633 Apostolaki E, Tsagaraki T,Tsapakis M, Karakassis I. 2007. Fish farming impact on sediments 634 and macrofauna associated with seagrass meadows in the Mediterranean. Estuarine, Coastal and 635 Shelf Science 75:408-416.Apostolaki ET, Marbà N, Holmer M, Karakassis I. 2009. Fish farming 636 enhances biomass and nutrient loss in Posidonia oceanica (L.) Delile. Estuarine, Coastal and 637 Shelf Science 8:390-400. https://doi.org/10.1016/j.ecss.2008.11.014.

638 Apostalaki ET, Vizzini S, Karakassis I. 2012. Leaf vs. epiphyte nitrogen uptake in a nutrient 639 enriched Mediterranean seagrass (Posidonia oceanica) meadow. Aquatic Botany 96:58-62.

640 https://doi.org/10.1016/j.aquabot.2011.09.008.

641 Ben Brahim M, Mabrouk L, Hamza A, Mahfoudi M, Bouain A, Aleya L. 2014. Bathymetric 642 variation of epiphytic assemblages on Posidonia oceanica (L.) Delile leaves in relation to 643 anthropogenic disturbance in the southeastern Mediterranean. Environmental Science and 644 Pollution Research 21:13588-13601. https://doi.org/10.1007/s11356-014-3315-8.

645 Boström C, Bonsdorff E. 1997. Community structure and spatial variation of benthic 646 invertebrates associated with Zostera marina (L.) beds in the northern Baltic Sea. Journal of Sea 647 Research 37:153-166. https://doi.org/10.1016/S1385-1101(96)00007-X.

648 Boström C, Jackson EL, Simenstad CA. 2006. Seagrass landscapes and their effects on 649 associated fauna: a review. Estuarine, Coastal and Shelf Science 68:383-403.

650 doi:10.1016/j.ecss.2006.01.026. 
651 Brooks KM, Stierns AR, Backman C. 2004. Seven year remediation study at the Carrie Bay 652 Atlantic salmon (Salmo salar) farm in the Broughton Archipelago, British Columbia, Canada. 653 Aquaculture 239:81-123. doi:10.1016/j.aquaculture.2003.12.024.

654 Canadian Department of Fisheries and Oceans (DFO). 2007. Port Mouton Site Review. DFO 655 Canadian Advisory Secretariat Science Advisory Report 2007/009.

656 Canadian Department of Fisheries and Oceans (DFO). 2009a. Does eelgrass (Zostera marina) 657 meet the criteria as an ecologically significant species? DFO Canadian Science Advisory 658 Secretariat Science Advisory Report 2009/018.

659 Canadian Department of Fisheries and Oceans (DFO). 2009b. Review of cumulative effects 660 report for Port Mouton, Nova Scotia. DFO Canadian Science Advisory Secretariat Science 661 Advisory Report 2008/015.

662 Canadian Department of Fisheries and Oceans (DFO). 2012. Definitions of harmful alteration, 663 disruption or destruction (HADD) of habitat provided by eelgrass (Zostera marina). DFO 664 Canadian Science Advisory Secretariat Science Advisory Report 2011/058.

665 Cancemi G, De Falco G, Pergent G. 2003. Effects of organic matter input from a fish farming 666 facility on a Posidonia oceanica meadow. Estuarine Coastal and Shelf Science 56:961-968. 667 https://doi.org/10.1016/S0272-7714(02)00295-0.

668 Clarke K, Gorley R. 2015. Primer v7: User manual/tutorial. Plymouth: PRIMER-E Ltd.

669 Cullain N, McIver, R, Schmidt AL, Lotze HK. 2017. Spatial variation of macroinfaunal 670 communities associated with Zostera marina beds across three biogeographic regions in Atlantic 671 Canada. Estuaries and Coasts 41:1381-1396. https://doi.org/10.1007/s12237-017-0354-7.

672 Dalsgaard T, Krause-Jensen D. 2006. Monitoring nutrient release from fish farms with 673 macroalgal and phytoplankton bioassays. Aquaculture 256:302-310.

674 https://doi.org/10.1016/j.aquaculture.2006.02.047.

675 Delgado O, Ruiz J, Perez M, Romero J, Ballesteros E. 1999. Effects of fish farming on seagrass 676 (Posidonia oceanica) in a Mediterranean bay: seagrass decline after organic loading cessation. 677 Oceanological Acta 22:109-117. https://doi.org/10.1016/S0399-1784(99)80037-1.

678 Díaz-Almela E, Marba N, Alvarez E, Santiago R, Holmer M, Grau A, Mirto S, Danovaro R, 679 Petrou A, Argyrou M, Karakassis I, Duarte CM. 2008. Benthic input rates predict seagrass 680 (Posidonia oceanica) fish farm-induced decline. Marine Pollution Bulletin 56:1332-1342. 681 https://doi.org/10.1016/j.marpolbul.2008.03.022.

682 Dolenec T, Lojen S, Lambaša Ž, Dolenec M. 2006. Effects of fish farm loading on seagrass 683 Posidonia oceanica at Vrgada Island (Central Adriatic): a nitrogen stable isotope study. Isotopes 684 in Environmental and Health Studies 42:77-85. https://doi.org/10.1080/10256010500384697.

685 Duarte CM, Kirkman H. 2001. Methods for the measurement of seagrass abundance and depth 686 distribution. In Short FT, Coles RJ (eds) Global Seagrass Research Methods. Elsevier. p. 141687153.

688 Duarte CM. 2002. The future of seagrass meadows. Environmental Conservation 29:192-206. 689 https://doi.org/10.1017/S0376892902000127. 
690 EFSA Scientific Committee. 2011. Statistical significance and biological relevance. EFSA

691 Journal 9(9):2372. https://efsa.onlinelibrary.wiley.com/doi/epdf/10.2903/j.efsa.2011.2372.

692 Frederiksen M, Krause-Jensen D, Holmer M, Laursen JS. 2004. Spatial and temporal variation in 693 eelgrass (Zostera marina) landscapes: influence of physical setting. Aquatic Botany 78:147-165.

694 https://doi.org/10.1016/j.aquabot.2003.10.003.

695 Frederiksen MS, Holmer M, Diaz-Almela E, Marbà N, Duarte CM. 2007. Sulfide invasion in the 696 seagrass Posidonia oceanica along gradients of organic loading at Mediterranean fish farms:

697 assessment by stable sulfur isotopes. Marine Ecology Progress Series 345:93-104. doi:

$69810.3354 /$ meps06990.

699 García-Marín P, Cabaço S, Hernández I, Vergara JJ, Silva J, Santos R. 2013. Multi-metric index

700 based on the seagrass Zostera noltii (ZoNI) for ecological quality assessment of coastal and

701 estuarine systems in SW Iberian Peninsula. Marine Pollution Bulletin 68:46-54.

702 https://doi.org/10.1016/j.marpolbul.2012.12.025.

703 García-Sanz T, Ruiz JM, Pérez M, Ruiz M. 2011. Assessment of dissolved nutrients dispersal

704 derived from offshore fish-farm using nitrogen stable isotope ratios $(\delta 15 \mathrm{~N})$ in macroalgal

705 bioassays. Estuarine, Coastal and Shelf Science 91:361-370.

706 https://doi.org/10.1016/j.ecss.2010.10.025.

707 Gregory D, Petrie B, Jordan F, Langille P. 1993. Oceanongraphic, geographic and hydrological

708 parameters of Scotia-Fundy and Southern Gulf of St. Lawrence inlets. Canadian Technical

709 Report of Hydrography and Ocean Sciences 143. Ottawa: Department of Fisheries and Oceans

710 Canada.

711 Grice AM, Loneragan NR, Dennison WC. 1996. Light intensity and the interactions between

712 physiology, morphology and stable isotope ratios in five species of seagrass. Journal of

713 Experimental Marine Biology and Ecology 195:91-110. https://doi.org/10.1016/0022-

714 0981(95)00096-8.

715 Hasler-Sheetal H, Holmer M. 2015. Sulfide intrusion and detoxification in the seagrass

716 Zostera marina. PLoS One 10(6): e0129136. https://doi.org/10.1371/journal.pone.0129136.

717 Hardison AK, Canuel EA, Anderson IC, Tobias CR, Veuger B, Waters MN. 2013.

718 Microphytobenthos and benthic macroalgae determine sediment organic matter composition in

719 shallow photic sediments. Biogeosciences 10:5571-5588. https://doi.org/10.5194/bg-10-5571-

7202013.

721 Hargrave BT. 2002. A traffic light decision system for marine finfish aquaculture siting. Ocean

722 \& Coastal Management 45:215-235. https://doi.org/10.1016/S0964-5691(02)00056-X.

723 Hargrave BT. 2010. Empirical relationships describing benthic impacts of salmon aquaculture.

724 Aquaculture Environment Interactions 1:33-46. https://doi.org/10.3354/aei00005.

725 Hauxwell J, Cebrian J, Valiela I. 2003. Eelgrass Zostera marina loss in temperate estuaries:

726 Relationship to land-derived nitrogen loads and effect of light limitation imposed by algae.

727 Marine Ecology Progress Series 247:59-73. doi:10.3354/meps247059.

728 Hemminga MA, Mateo MA. 1996. Stable carbon isotopes in seagrasses: variability in ratios and

729 use in ecological studies. Marine Ecology Progress Series 140:285-298.

730 doi:10.3354/meps14028. 
731 Hemminga MA, Duarte CM. 2000. Seagrass ecology. Cambridge: Cambridge University Press, 732 UK.

733 Holmer M, Bondgaard EJ. 2001. Photosynthetic and growth response of eelgrass to low oxygen

734 and high sulfide concentrations during hypoxic events. Aquatic Botany 70:29-38.

735 https://doi.org/10.1016/S0304-3770(00)00142-X.

736 Holmer M, Duarte CM, Boschker HTS, Barron C. 2004. Carbon cycling and bacterial carbon

737 sources in pristine and impacted Mediterranean seagrass sediments. Aquatic Microbial Ecology

738 36:227-237. doi:10.3354/ame036227.

739 Holmer M, Wildish D, Hargrave B. 2005. Organic enrichment from marine finfish aquaculture

740 and effects on sediment processes. In: Hargrave BT, ed. Environmental effects of marine finfish

741 aquaculture, Vol. 5M. Berlin: Springer, 181-206.

742 Holmer M, Marba N, Diaz-Almela E, Duarte CM, Tsapakis M, Danovaro R. 2007.

743 Sedimentation of organic matter from fish farms in oligotrophic Mediterranean assessed through

744 bulk and stable isotope ( $\delta 13 \mathrm{C}$ and $\delta 15 \mathrm{~N})$ analyses. Aquaculture 262:268-280.

745 https://doi.org/10.1016/j.aquaculture.2006.09.033.

746 Holmer M, Argyrou M, Dalsgaard T, Danovaro R, Diaz-Almela E, Duarte CM, Frederiksen M,

747 Grau A, Karakassis I, Marbà N, Mirto S, Pérez M, Pusceddu A, Tsapakis M. 2008. Effects of

748 fish farm waste on Posidonia oceanica meadows: Synthesis and provision of monitoring and

749 management tools. Marine Pollution Bulletin 56(9):1618-1629.

750 https://doi.org/10.1016/j.marpolbul.2008.05.020.

751 Karakassis I, Hatziyanni E, Tsapakis M, Plaiti W. 1999. Benthic recovery following cessation of

752 fish farming: a series of successes and catastrophes. Marine Ecology Progress Series 184:205-

753 218. doi:10.3354/meps 184205.

754 Karakassis I, Papageorgiou N, Kalantzi I, Sevastou K, Koutsikopoulos C. 2013. Adaptation of

755 fish farming production to the environmental characteristics of the receiving marine ecosystems:

756 A proxy to carrying capacity. Aquaculture 408-409:184-190.

757 https://doi.org/10.1016/j.aquaculture.2013.06.002.

758 Larkum AWD, Orth RJ, Duarte CM. 2006. Seagrasses: Biology, ecology, and conservation.

759 Springer.

760 La Rosa T, Mirto S, Mazzola A, Danovaro R. 2001. Di $\square$ erential responses of benthic microbes

761 and meiofauna to fish-farm disturbance in coastal sediments. Environmental Pollution 112, 427-

762 434. https://doi.org/10.1016/S0269-7491(00)00141-X.

763 Lee S. 2014. Combining local ecological knowledge and conventional science to assess the

764 dynamics of eelgrass (Zostera marina) in relation to finfish aquaculture operation in Port

765 Mouton Bay, Nova Scotia. Thesis. Dalhousie University, Canada.

766 Lee HW, Bailey-Brock JH, McGurr MM. 2006. Temporal changes in the polychaete infaunal

767 community surrounding a Hawaiian mariculture operation. Marine Ecology Progress Series

768 307:175-185. doi:10.3354/meps307175.

769 Leopardas V, Honda K, Go GA, Bolisay K, Pantallano AD, Uy W, Fortes M, Nakaoka M. 2015.

770 Variation in macrofaunal communities of sea grass beds along a pollution gradient in Bolinao, 
771 northwestern Philippines. Marine Pollution Bulletin 105:310-318.

772 doi:10.1016/j.marpolbul.2016.02.004.

773 Lepoint G, Dauby P, Gobert S. 2004. Applications of C and N stable isotopes to ecological and

774 environmental studies in seagrass ecosystems. Marine Pollution Bulletin 49:887-891.

775 https://doi.org/10.1016/j.marpolbul.2004.07.005.

776 Lever MA, Valiela I. 2005. Response of microphytobenthic biomass to experimental nutrient

777 enrichment and grazer exclusion at different land-derived nitrogen loads. Marine Ecology

778 Progress Series 294:117-129. doi:10.3354/meps294117.

779 Lin DT, Beiley-Brock JH. 2008. Partial recovery of infaunal communities during a fallow period

780 at an open-ocean aquaculture. Marine Ecology Progress Series 371:65-72.

781 https://doi.org/10.3354/meps07675.

782 Longstaff BJ, Dennison WC. 1999. Seagrass survival during pulsed turbidity events: the effects

783 of light deprivation on the seagrasses Halodule pinifolia and Halophila ovalis. Aquatic Botany

784 65:105-121. https://doi.org/10.1016/S0304-3770(99)00035-2.

785 Luckenbach ML, Orth RJ. 1999. Effects of a deposit-feeding invertebrate on the entrapment of

786 Zostera marina L. seeds. Aquatic Botany 62:235-247. https://doi.org/10.1016/S0304-

787 3770(98)00098-9.

788 Luczak C, Janquin MA, Kupka A. 1997. Simple standard procedure for the routine determination

789 of organic matter in marine sediment. Hydrobiologia 345:87-94.

790 doi:10.1023/A:1002902626798.

791 Marbà N, Duarte CM. 1998. Rhizome elongation and seagrass clonal growth. Marine Ecology

792 Progress Series 174:269-280. doi:10.3354/meps174269.

793 Martinez-Garcia E, Pablo Sanchez-Jerez P, Aguado-Giménez F, Ávila P, Guerrero A, Sánchez-

794 Lizaso JL, Fernandez-Gonzalez V, González N, Gairin JI, Carballeira C, Gárcia-Gárcia B,

795 Carreras J, Macías JC, Carballeria A, Collado C. 2013. A meta-analysis approach to the effects

796 of fish farming on soft bottom polychaeta assemblages in temperate regions. Marine Pollution

797 Bulletin 69:165-171. https://doi.org/10.1016/j.marpolbul.2013.01.032.

798 McIver R, Milewski I, Lotze HK. 2015. Land use and nitrogen loading in seven estuaries along

799 the southern Gulf of St. Lawrence, Canada. Estuarine, Coastal Shelf Science 165:137-148.

800 https://doi.org/10.1016/j.ecss.2015.08.011.

801 McIver R, Milewski I, Loucks R, Smith R. 2018. Estimating nitrogen loading and far-field

802 dispersal potential from background sources and coastal finfish aquaculture: a simple framework

803 and case study in Atlantic Canada. Estuarine, Coastal and Shelf Science 205:46-57.

804 https://doi.org/10.1016/j.ecss.2018.01.005.

805 Meyer-Reil L-A, Köster M. 2000. Eutrophication of marine waters: effects on benthic microbial

806 communities. Marine Pollution Bulletin 41:255-63. https://doi.org/10.1016/S0025-

807 326X(00)00114-4.

808 Nagel EJ, Murphy G, Wong MC, Lotze HK. 2018. Nitrogen loading rates for twenty-one

809 seagrass inhabited bays in Nova Scotia. Canadian Technical Report of Fisheries and Aquatic

810 Sciences 3260. http://waves-vagues.dfo-mpo.gc.ca/Library/4068099x.pdf.

811 Nova Scotia Department of Fisheries and Aquaculture (NSDFA). 2014. Environmental 
812 Monitoring Program. Level II monitoring results for Port Mouton lease \#0835 (Spectacle Island)

813 July 16, 2014. NSDFA. 2017. Public Information. https://novascotia.ca/fish/aquaculture/public-

814 information/ (accessed February 10, 2018).

815 Oliva S, Mascaró O, Llagostera I, Pérez M, Romero J. 2012. Selection of metrics based on the

816 seagrass Cymodocea nodosa and development of a biotic index (CYMOX) for assessing

817 ecological status of coastal and transitional waters. Estuarine, Coastal and Shelf Science 114:7-

818 17. https://doi.org/10.1016/j.ecss.2011.08.022.

819 Olsen L, Holmer M, Olsen Y. 2008. Perspectives of nutrient emission from fish aquaculture in 820 coastal waters: literature review with evaluated state of knowledge. Final report FHF project no.

821 542014. The Fishery and Aquaculture Industry Research Fund, Oslo, p. 87.

822 Orth RJ, Heck, Jr. KL, van Montfrans J. 1984. Faunal communities in seagrass beds: A review of 823 the influence of plant structure and prey characteristics on predator-prey relationships. Estuaries 824 7:339-350. https://doi.org/10.2307/1351618.

825 Orth RJ, Carruthers TJB, Dennison WC, Duarte CM, Fourqurean JW, Heck KL, Hughes AR, 826 Kendrick GA, Kenworthy WJ, Olyarnik S, Short FT, Waycott M, Williams SL. 2006. A global 827 crisis for seagrass ecosystems. Biosciences 56: 987-996. https://doi.org/10.1641/0006828 3568(2006)56[987:AGCFSE]2.0.CO;2.

829 Pearson TH, Rosenberg R. 1978. Macrobenthic succession in relation to organic enrichment and 830 pollution of the marine environment. Oceanography and Marine Biology: An Annual Review 831 16:229-311.

832 Pearson TH, Gray JS, Johannessen PJ. 1983. Objective selection of sensitive species indicative 833 of pollution-induced change in benthic communities. 2. Data analysis. Marine Ecology Progress 834 Series 12:237-255.

835 Pereira PMF, Black KD, McLusky DS, Nickell TD. 2004. Recovery of sediments after cessation 836 of marine fish farm production. Aquaculture 235:315-330.

837 https://doi.org/10.1016/j.aquaculture.2003.12.023.

838 Pérez M, García T, Invers O, Ruiz JM. 2008. Physiological responses of the seagrass Posidonia 839 oceanica as indicators of fish farm impact. Marine Pollution Bulletin 56:869-879.

840 https://doi.org/10.1016/j.marpolbul.2008.02.001.

841 Pergent-Martini C, Boudouresque CF, Pasqualini V, Pergent G. 2006. Impact of fish farming

842 facilities on Posidonia oceanica meadows: A review. Marine Ecology 27:310-319.

843 doi:10.1111/j.1439-0485.2006.00122.x.

844 Pitta P, Apostolaki ET, Tsagaraki T, Tsapakis M, Karakassis I. 2006. Fish farming effects on 845 chemical and microbial variables of the water column: a spatio-temporal study along the 846 Mediterranean Sea. Hydrobiologia 563:99-108. http:// doi 10.1007/s10750-005-1593-3.

847 Piper DJW, Mudie PJ, Letson JRJ, Barnes NE, Iuliucci RJ. 1986. The Marine Geology of the 848 inner Scotian Shelf off the South Shore, Nova Scotia. In: Geological Survey of Canada Paper 849 85-19. Ottawa: Geological Survey of Canada.

850 Price C, Black KD, Hargrave BT, Morris JA Jr. 2015. Marine cage culture and the environment: 851 effects on water quality and primary production. Aquaculture Environment Interactions 6:151-

852 174. doi:10.3354/aei00122. 
853 Roca G, Alcoverro T, Krause-Jensen D, Balsby TJS, van Katwijk MM, Marbà N, Santos R,

854 Arthur R, Mascaró O, Fernández-Torquemada Y, Pérez M, Duarte CM, Romeroa J. 2016.

855 Response of seagrass indicators to shifts in environmental stressors: A global review and

856 management synthesis. Ecological Indicators 63:310-323.

857 https://doi.org/10.1016/j.ecolind.2015.12.007.

858 Romero J, Martínez-Crego B, Alcoverro T, Pérez M. 2007. A multivariate index based on the

859 seagrass Posidonia oceanica (POMI) to assess ecological status of coastal waters under the water

860 framework directive (WFD). Marine Pollution Bulletin 55:96-204.

861 https://doi.org/10.1016/j.marpolbul.2006.08.032.

862 Rountos KJ, Peterson BJ, Karakassis I. 2012. Indirect effects of fish cage aquaculture on shallow

863 Posidonia oceanica seagrass patches in coastal Greek waters. Aquaculture Environment

864 Interactions 2:105-115. doi:10.3354/aei00037.

865 Ruiz JM, Pérez M, Romero J. 2001. Effects of fish farm loadings on seagrass (Posidonia

866 oceanica) distribution, growth and photosynthesis. Marine Pollution Bulletin 42:749-760.

867 https://doi.org/10.1016/S0025-326X(00)00215-0.

868 Ruiz JM, Marco-Méndez C, Sánchez-Lizaso JL. 2010. Remote influence of off-shore fish farm

869 waste on Mediterranean seagrass (Posidonia oceanica) meadows. Marine Environmental

870 Research 69:118-126. doi:10.1016/j.marenvres.2009.09.002.

871 Sarà G, Scilipoti D, Milazzo M, Modica A. 2006. Use of stable isotopes to investigate the

872 dispersion of fish farming waste as a function of hydrodynamics. Marine Ecology Progress

873 Series 313:261-270. doi:10.3354/meps313261.

874 Schmidt AL, Coll M, Romanuk TN, Lotze HK. 2011. Ecosystem structure and services in 875 eelgrass Zostera marina and rockweed Ascophyllum nodosum habitats. Marine Ecology Progress

876 Series 437, 51-68. https://doi.org/10.3354/meps09276.

877 Schmidt AL, Wysmyk JKC, Craig SE, Lotze HK. 2012. Regional-scale effects of eutrophication

878 on ecosystem structure and services of seagrass beds. Limnology Oceanography 57:1389-1402.

879 doi:10.4319/1o.2012.57.5.1389.

880 Schubert PR, Karez R, Reusch TBH, Dierking J. 2013. Isotopic signatures of eelgrass (Zostera 881 marina L.) as bioindicator of anthropogenic nutrient input in the western Baltic Sea. Marine 882 Pollution Bulletin 72:64-70. doi:10.1016/j.marpolbul.2013.04.029.

883 Short FT, Polidoro B, Livingstone SR, Carpenter KE, Bandeira S, Sidik J, Calumpong HP, 884 Carruthers TJB, Coles RG, Dennison WC, Erftemeijer PLA, Fortes MD, Freeman AS, Jagtap 885 TG, Kamal AHM, Kendrick GA, Kenworthy WJ, La Nafie YA, Nasution IM, Orth RJ, Prathep 886 A, Sanciangco JC, van Tussenbroek B, Vergara SG, Waycott M, Zieman JC. 2011. Extinction 887 risk assessment of the world's seagrass species. Biological Conservation 144:1961-1971.

888 https://doi.org/10.1016/j.biocon.2011.04.010.

889 Sundbäck K, Linares F, Larson F, Wulff A. 2004. Benthic nitrogen fluxes along a depth gradient 890 in a microtidal fjord: the role of denitrification and microphytobenthos. Limnology and 891 Oceanography 49:1095-1107. doi:10.4319/1o.2004.49.4.1095.

892 Telesca L, Belluscio A, Criscoli A, Ardizzone G, Apostolaki ET, Fraschetti S, Gristina M,

893 Knittweis L, Martin CS, Pergent G, Alagna A, Badalamenti F, Garofalo G, Gerakaris V, Louise 
894 Pace M, Pergent-Martini C, Salomidi M. 2015. Seagrass meadows (Posidonia oceanica)

895 distribution and trajectories of change. Scientific Reports 5:12505. doi:10.1038/srep12505.

896 Terlizzi A, De Falco G, Felline S, Fiorentino D, Gambi MC, Cancemi G. 2010. Effects of marine 897 cage aquaculture on macrofauna assemblages associated to Posidonia oceanica meadows. Italian 898 Journal of Zoology 77:362-371. https://doi.org/10.1080/11250000903464075.

899 Vandermeulen, H. 2005. Assessing marine habitat sensitivity: A case study with eelgrass

900 (Zostera marina L.) and kelps (Laminaria, Macrocystis). DFO Canadian Science Advisory

901 Secretariat Research Document 2005/032. Ottawa: Department of Fisheries and Oceans Canada.

902 Vizzini S, Mazzola A. 2004. Stable isotope evidence for the environmental impact of a land-

903 based fish farm in the western Mediterranean. Marine Pollution Bulletin 49:61-70.

904 https://doi.org/10.1016/j.marpolbul.2004.01.008.

905 Warwick RM. 1986. A new method for detecting pollution effects on marine macrobenthic 906 communities. Marine Biology 92(4):557-562. https://doi.org/10.1007/BF00392515.

907 Warwick RM and Pearson TH. 1987. Detection of pollution effects on marine macrobenthos:

908 further evaluation of the species abundance/biomass method. Marine Biology 95:193-200.

909 https://doi.org/10.1007/BF00409005.

910 Waycott M, Duarte CM, Carruthers TJB, Orth RJ, Dennison WC, Olyarnik S, Calladine A, 911 Fourqurean JW, Heck KL, Hughes AR, Kendrick GA, Kenworthy WJ, Short FT, Williams SL.

912 2009. Accelerating loss of seagrasses across the globe threatens coastal ecosystems. Proceedings

913 of the National Academy of Sciences 106:12377-12381.

914 https://doi.org/10.1073/pnas.0905620106.

915 Worm B, Lotze HK. 2006. Effects of eutrophication, grazing, and algal blooms on rocky shores.

916 Limnology Oceanography 51:569-579. doi:10.4319/lo.2006.51.1_part_2.0569.

917 


\section{Table $\mathbf{1}$ (on next page)}

Overview of published responses of seagrass (Posidonia oceanica) variables (Metrics) at different levels of organization (Level) in the proximity to netpen fish farms in the Mediterranean Sea.

Abbreviations refer to: $\mathrm{C}$, carbon; $\mathrm{N}$, nitrogen; $\mathrm{P}$, phosphorus; $\mathrm{S}$, sulphur; $\delta$, stable isotope ratios, L, leaves; $R$, roots; Rh, rhizomes; $A G$, aboveground; $B G$, belowground; Chl-a, chlorophyll; J', evenness index; $1-\lambda^{\prime}$, Simpson's diversity index. 


\begin{tabular}{|c|c|c|c|}
\hline Level & Metric & Response & References \\
\hline $\begin{array}{l}\text { Physiological: } \\
\text { tissue } \\
\text { variables }\end{array}$ & $\begin{array}{l}\mathrm{N} \text { and } \mathrm{C} \text { content in } \mathrm{L}, \mathrm{R} \text { or } \mathrm{Rh} \\
\mathrm{P} \text { content in } \mathrm{L}, \mathrm{R} \text { or } \mathrm{Rh} \\
\mathrm{S} \text { content in } \mathrm{R} \text { or } \mathrm{Rh} \\
\delta^{15} \mathrm{~N} \text { in } \mathrm{L}, \mathrm{R} \text { or } \mathrm{Rh} \\
\delta^{13} \mathrm{C} \text { in } \mathrm{L}, \mathrm{R} \text { or } \mathrm{Rh} \\
\delta^{34} \mathrm{~S} \text { in } \mathrm{R} \text { or } \mathrm{Rh} \\
\text { Sucrose (total non-structural } \\
\quad \text { carbohydrates) in } \mathrm{R} \text { or } \mathrm{Rh}\end{array}$ & $\begin{array}{l}\text { increase } \\
\text { increase } \\
\text { increase } \\
\text { increase } \\
\text { increase } \\
\text { increase } \\
\text { decrease }\end{array}$ & $\begin{array}{l}\text { Pérez et al., 2008; Rountos et al., } 2012 \\
\text { Apostolaki et al., } 2009 \\
\text { Frederickson et al., } 2007 \\
\text { Vizzini \& Mazzola, 2004; Dolenec et al. 2006; } \\
\quad \text { Ruiz et al., 2010 } \\
\text { Vizzini \& Mazzola, 2004; Holmer et al., } 2004 \\
\text { Frederickson et al., 2007 } \\
\text { Delgado et al., 1999; Ruiz et al., 2001; Pérez et } \\
\quad \text { al., } 2008\end{array}$ \\
\hline $\begin{array}{l}\text { Individual: } \\
\text { plant growth }\end{array}$ & $\begin{array}{l}\text { Leaf morphometrics (length or } \\
\text { width) } \\
\text { Rhizome growth }\end{array}$ & $\begin{array}{l}\text { decrease } \\
\text { decrease }\end{array}$ & $\begin{array}{l}\text { Delgado et al. 1999; Apostolaki et al. 2009; } \\
\quad \text { Rountos et al., 2012 } \\
\text { Cancemi et al., 2003; Marbà et al., } 2006\end{array}$ \\
\hline $\begin{array}{l}\text { Population: } \\
\text { canopy } \\
\text { structure }\end{array}$ & $\begin{array}{l}\text { Shoot density } \\
\text { \% Cover } \\
\text { Shoot mortality } \\
\text { Total Biomass } \\
\text { AG and BG biomass } \\
\text { Ratio AG to BG biomass }\end{array}$ & $\begin{array}{l}\text { decrease } \\
\text { increase } \\
\text { decrease } \\
\text { decrease } \\
\text { decrease }\end{array}$ & $\begin{array}{l}\text { Delgado et al., 1999; Cancemi et al., 2003; } \\
\text { Pergent-Martini et al., 2006; Díaz-Almela et } \\
\text { al., 2008; Holmer et al., 2008; Apostolaki et al. } \\
\text { 2009; Rountos et al., 2012 } \\
\text { Ruiz et al., 2001; Cancemi et al., 2003; Holmer et } \\
\text { al. } 2008 \\
\text { Delgado et al., 1999; Díaz-Almela et al., 2008; } \\
\text { Holmer et al., 2008 } \\
\text { Delgado et al., 1999; Rountos et al., } 2012 \\
\text { Delgado et al., 1999; Apostolaki et al. } 2009 \\
\text { Apostolaki et al. } 2009\end{array}$ \\
\hline $\begin{array}{l}\text { Community: } \\
\text { associated } \\
\text { flora and } \\
\text { fauna }\end{array}$ & $\begin{array}{l}\text { Epiphyte N and P content and } \\
\quad \delta^{15} \mathrm{~N} \\
\text { Microphytobenthos }(\mathrm{Chl}-a) \\
\text { Phytoplankton }(\mathrm{Chl}-a) \\
\text { Annual macroalgal growth } \\
\text { Meiofaunal abundance } \\
\text { Meiofaunal taxon richness } \\
\text { Macrofaunal abundance } \\
\text { Macrofaunal diversity }\left(\mathrm{J}^{\prime}, 1-\lambda^{\prime}\right) \\
\text { Herbivory }\end{array}$ & $\begin{array}{l}\text { increase } \\
\text { increase } \\
\text { increase } \\
\text { increase } \\
\text { increase } \\
\text { decrease } \\
\text { increase } \\
\text { decrease } \\
\text { increase }\end{array}$ & $\begin{array}{l}\text { Pergent et al 1999; Cancemi et al. 2003; Ruiz et } \\
\quad \text { al. 2001; Vizzini \& Mazzola, 2004; Pérez et al. } \\
\text { 2008; Rountos et al., } 2012 \\
\text { Pérez et al., 2008; Ruiz et al., 2010; Apostolaki et } \\
\quad \text { al., 2007, 2012 } \\
\text { La Rosa et al., 2001 } \\
\text { Pitta et al., 2006; Dalsgaard \& Krause-Jensen, } \\
\quad 2006 \\
\text { Dalsgaard \& Krause-Jensen, } 2006 \\
\text { La Rosa et al., 2001; Holmer et al., 2008 } \\
\text { Holmer et al., 2008 } \\
\text { Terlizzi et al., 2010 } \\
\text { Terlizzi et al., 2010 } \\
\text { Pergent et al., 1999; Ruiz et al., 2001; Holmer et } \\
\quad \text { al., 2008 }\end{array}$ \\
\hline
\end{tabular}




\section{Table 2 (on next page)}

Site names with their abbreviations and associated distance from the finfish farm, bottom temperature, depth and bottom type.

Included are the four study sites sampled in July 2015 (SI, CB, OW, PJ), and 7 other Nova Scotia (NS) sites without finfish farms for comparison (below the black line; GB, ST, FG, CR, SM, FP, TH) located along the Atlantic Coast of Canada (Figure 1). The three sites in Port Mouton Bay (SI, CB, OW) were located at varying distances from a finfish farm, and our reference site (PJ) was in adjacent Port Joli Bay. Bottom types include sand (S), mud (M), muddy sand (MS), cobble and sand (CS), and sand and boulders (SB). - means that the distance is not relevant. 
1

\begin{tabular}{lcccc}
\hline Site (Abbreviation) & $\begin{array}{c}\text { Distance } \\
(\mathrm{km})\end{array}$ & $\begin{array}{c}\text { Temp. } \\
\left({ }^{\circ} \mathrm{C}\right)\end{array}$ & $\begin{array}{c}\text { Depth } \\
(\mathrm{m})\end{array}$ & $\begin{array}{c}\text { Bottom } \\
\text { type }\end{array}$ \\
\hline Spectacle Island (SI) & 0.3 & 15 & 2.0 & $\mathrm{MS}$ \\
Carters Beach (CB) & 0.7 & 12 & 2.5 & $\mathrm{~S}$ \\
Old Wharf (OW) & 3 & 14 & 1.7 & $\mathrm{MS}$ \\
Port Joli (PJ) & $>10$ & 15 & 2.9 & $\mathrm{SB}$ \\
\hline Green Bay (GB) & - & 14 & 1.4 & $\mathrm{M}$ \\
Strawberry Island (ST) & - & 14 & 4.4 & $\mathrm{CS}$ \\
Franks George Island (FG) & - & 15 & 4.3 & $\mathrm{~S}$ \\
Croucher Island (CR) & - & 15 & 3.6 & $\mathrm{~S}$ \\
Inner Sambro Island (SM) & - & 12 & 4.8 & $\mathrm{~S}$ \\
False Passage (FP) & - & 12 & 4.6 & $\mathrm{~S}$ \\
Taylor Head Provincial Park (TH) & - & 10 & 4.9 & $\mathrm{SB}$ \\
\hline
\end{tabular}

2 


\section{Table 3 (on next page)}

Results from multivariate and univariate PERMANOVAs on the effect of site on environmental variables, eelgrass tissue and eelgrass canopy structure across sites.

Included are the four study sites and an average of the other NS sites for comparison along the Atlantic Coast of Canada. Multivariate analyses were only performed for non-independent variables, and only followed up with univariate analyses if statistically significant differences ( $p \leq 0.05$, bolded) were found or ecologically relevant patterns from other studies were observed in our data (e.g. \%N). 


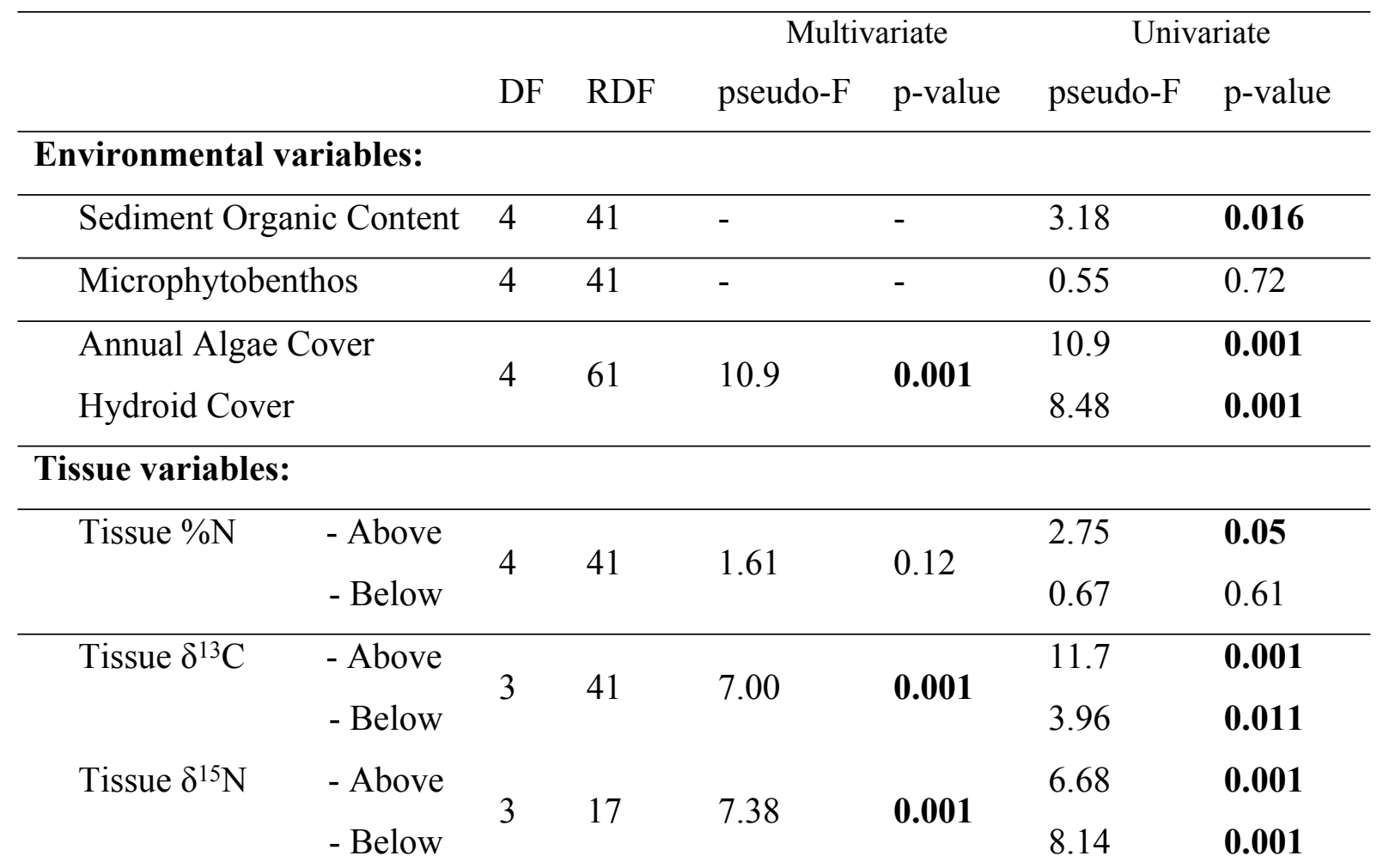

\begin{tabular}{|c|c|c|c|c|c|c|}
\hline Eelgrass bed structure: & & & & & & \\
\hline Shoot Density & \multirow{2}{*}{4} & \multirow{2}{*}{61} & \multirow{2}{*}{1.44} & \multirow{2}{*}{0.20} & - & - \\
\hline Canopy Height & & & & & - & - \\
\hline Percent Cover & 4 & 61 & - & - & 2.81 & $\mathbf{0 . 0 3 7}$ \\
\hline \multirow[t]{2}{*}{ Biomass } & \multirow{2}{*}{4} & \multirow{2}{*}{61} & \multirow{2}{*}{2.28} & \multirow{2}{*}{0.02} & 2.46 & 0.063 \\
\hline & & & & & 2.11 & 0.083 \\
\hline
\end{tabular}




\section{Table 4 (on next page)}

Mean abundance ( $\mathrm{ABUN} ; \mathrm{m}^{-2}$ ) and biomass (BIOM; $\mathrm{g} \mathrm{m}^{-2}$ ) of the most abundant macroinfauna species $( \pm \mathrm{SE})$ at the four study sites.

From left to right: increasing distance from fish farm and control site (PJ), in Nova Scotia, Canada. Refer to Table 1 for site names and details. Species identified in the SIMPER analysis as contributing to $\geq 10 \%$ of the difference between sites are in bold. 


\begin{tabular}{lcccccccc}
\hline \multirow{2}{*}{ Species } & \multicolumn{2}{c}{ SI } & \multicolumn{2}{c}{ CB } & \multicolumn{2}{c}{ OW } & \multicolumn{2}{c}{ PJ } \\
\hline Amphitrite sp. & ABUN & BIOM & ABUN & BIOM & ABUN & BIOM & ABUN & BIOM \\
Capitella capitata & 0 & 0 & 0 & 0 & 0 & 0 & 31.9 & 105.6 \\
& 26.5 & 5.3 & 0 & 0 & 10.6 & 4.3 & 0 & 0 \\
Cerastoderma pinnulatum & $(12.8)$ & $(2.4)$ & & & $(6.7)$ & $(3.7)$ & & \\
& 0 & 0 & 15.9 & 0.7 & 0 & 0 & 0 & 0 \\
Clymenella torquata & 95.5 & 14.0 & 5.3 & 2.7 & 180.5 & 16.5 & 143.3 & 12.2 \\
& $(83.1)$ & $(13.8)$ & $(5.3)$ & $(2.7)$ & $(58.5)$ & $(7.6)$ & $(39.2)$ & $(4.9)$ \\
Nephtys sp. & 31.9 & 2.6 & 10.6 & 3.2 & 69.0 & 11.6 & 15.9 & 4.8 \\
& $(16.5)$ & $(1.3)$ & $(6.7)$ & $(2.2)$ & $(15.2)$ & $(3.4)$ & $(10.9)$ & $(4.2)$ \\
Ophelia sp. & 0 & 0 & 0 & 0 & 0 & 0 & 21.2 & 6.4 \\
Tellina agilis & & & & & & & $(15.8)$ & $(5.2)$ \\
& 5.3 & 0.2 & 15.9 & 0.4 & 0 & 0 & 0 & 0
\end{tabular}




\section{Table 5 (on next page)}

BIOENV results for the macroinfauna community and species identified by SIMPER analysis.

Included is abundance data (above the line) and biomass data (below the line) with environmental variables (percent cover of annual algae $(\% \mathrm{~A})$ and hydroids $(\% \mathrm{H})$, sediment organic content (SOC)), eelgrass tissue (belowground (BG) $\% \mathrm{~N}, \delta^{15} \mathrm{~N}$ and $\delta^{13} \mathrm{C}$ )and eelgrass canopy structure (BG biomass, Shoot density, Canopy height, Eelgrass cover) at the four study sites in Nova Scotia, Canada. Significant ( $p \leq 0.05)$ correlations are bolded. 


\begin{tabular}{llll}
\hline & Best correlated variable(s) & $\rho$ & p-value \\
\hline Community abundance & BG $\% \mathrm{~N}, \mathrm{BG} \delta^{13} \mathrm{C}, \% \mathrm{~A}$ & 0.45 & $\mathbf{0 . 0 2}$ \\
Capitella capitata & $\% \mathrm{H}$ & 0.45 & $\mathbf{0 . 0 4}$ \\
& SOC, \%H & 0.44 & \\
& $\mathrm{MPB}, \% \mathrm{H}$ & 0.44 & \\
Clymenella torquata & BG biomass & 0.47 & $\mathbf{0 . 0 1}$ \\
Nephtys sp. & BG biomass, Shoot density, SOC, & 0.21 & 0.13 \\
& Eelgrass cover & & \\
\hline Community biomass & BG biomass, BG \%N, BG $\delta^{13} \mathrm{C}$ & 0.40 & $\mathbf{0 . 0 4}$ \\
Amphitrite sp. & BG biomass & 0.21 & 0.82 \\
Capitella capitata & $\% \mathrm{H}$ & 0.50 & $\mathbf{0 . 0 2}$ \\
Clymenella torquata & BG biomass $\% \mathrm{H}$ & 0.46 & \\
Nephtys sp. & BG biomass, Shoot density & 0.43 & $\mathbf{0 . 0 1}$ \\
\hline
\end{tabular}

1 


\section{Figure 1}

Location of the study sites and other Nova Scotia (NS) sites for comparison.

All sites located along the Atlantic Coast of Canada (A) with a detailed map (B) of the location of the three study sites and the finfish farm in Port Mouton Bay and the reference site in Port Joli Bay. Historical eelgrass sites indicate areas where eelgrass was no longer present in July 2015. Refer to Table 2 for full site names and details. 


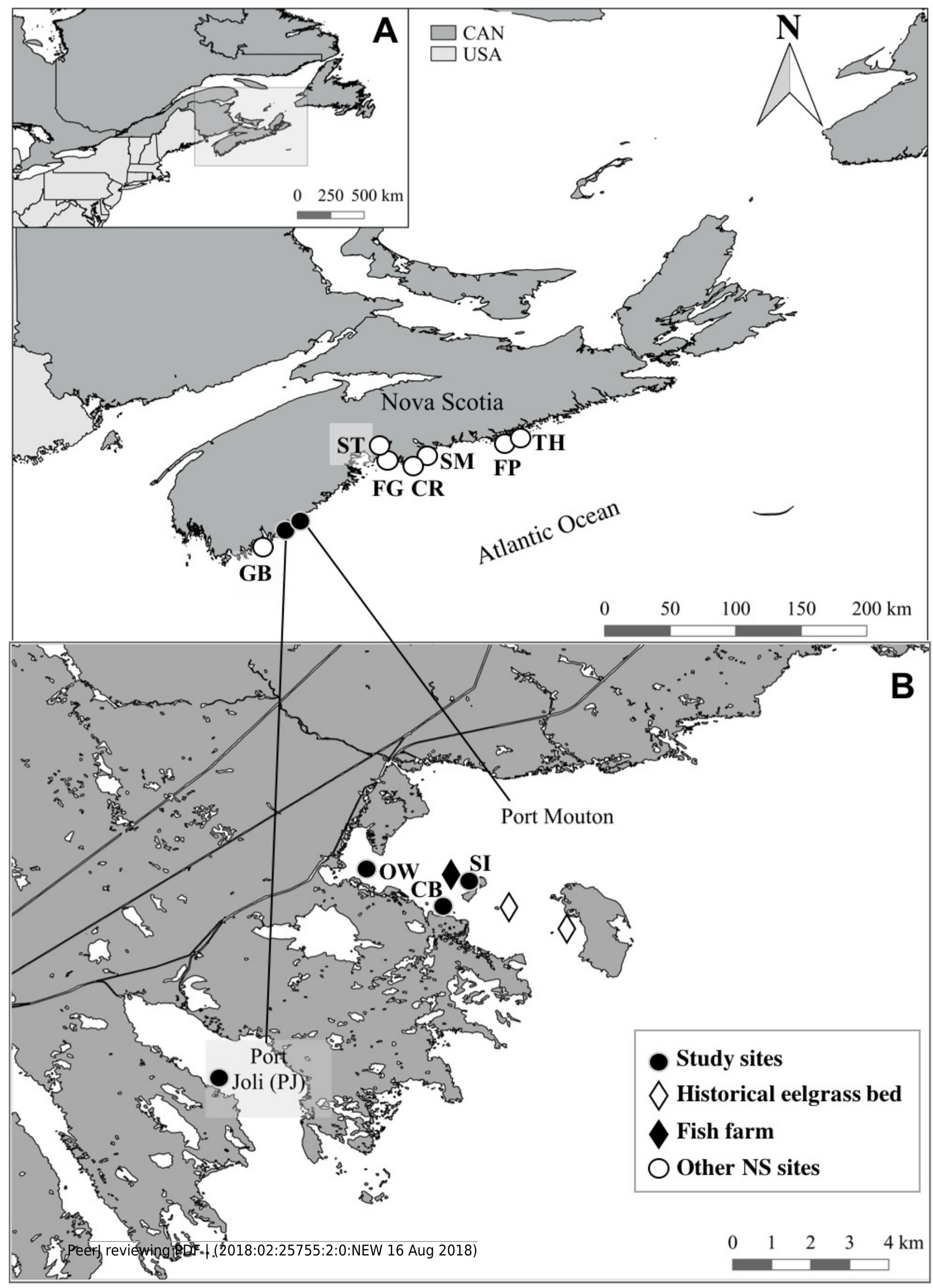




\section{Figure 2 (on next page)}

Environmental variables across the four study sites.

Environmental variables (mean $\pm \mathrm{SE}$ ) across the four study sites (from left to right: increasing distance from fish farm and PJ reference site) and an average of the other NS sites for comparison: a) sediment organic content, b) microphytobenthos chlorophyll-a concentration, and c) percent cover of epiphytic and benthic annual algae and epiphytic hydroids. Lower case letters indicate significant differences $(p \leq 0.05)$. If the lower-case letters in the same group are bolded, there is a marginally non-significant difference between those sites (i.e. p-value between 0.05- 0.1) for that variable. Number in brackets beside NS indicates the number of sites included in mean and statistical analyses. Refer to Table 1 for site abbreviations and details. 

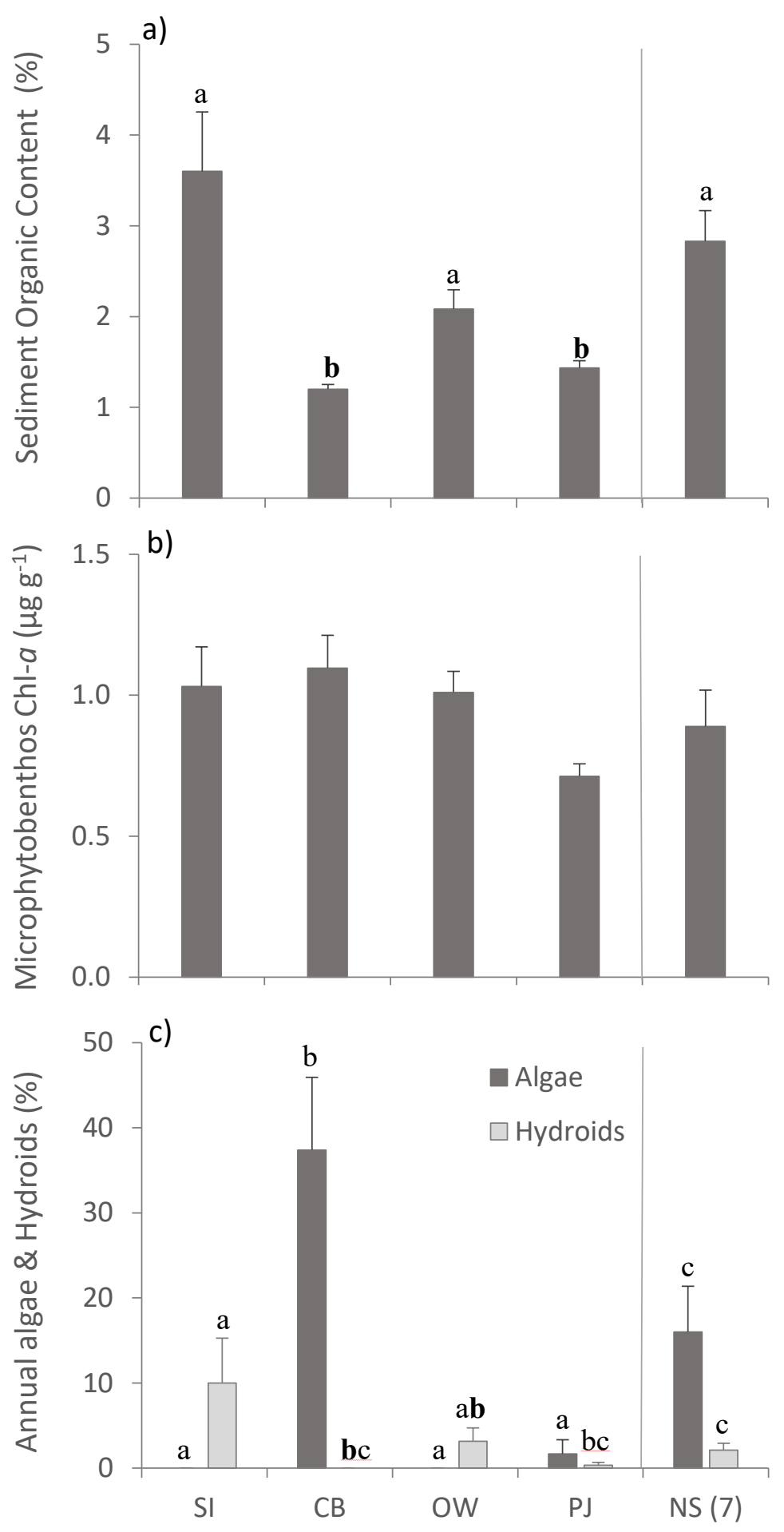


\section{Figure 3 (on next page)}

Eelgrass tissue variables (mean $\pm \mathrm{SE}$ ) across the four study sites (from left to right: increasing distance from farm and PJ reference site) and an average of the other NS sites for comparison.

a) eelgrass tissue nitrogen content $(\% \mathrm{~N})$ and stable isotope ratios of b) carbon ( $(813 \mathrm{C})$ and $c$ ) nitrogen $(\delta 15 \mathrm{~N})$ in above- and belowground tissues. Lower case letters indicate significant differences $(p \leq 0.05)$. If the lower-case letters in the same group are bolded, there is a marginally non-significant difference between those sites (i.e. p-value between 0.05- 0.1) for that variable. Number in brackets beside NS indicates the number of sites included in mean and statistical analyses. Refer to Table 1 for site abbreviations and details. 

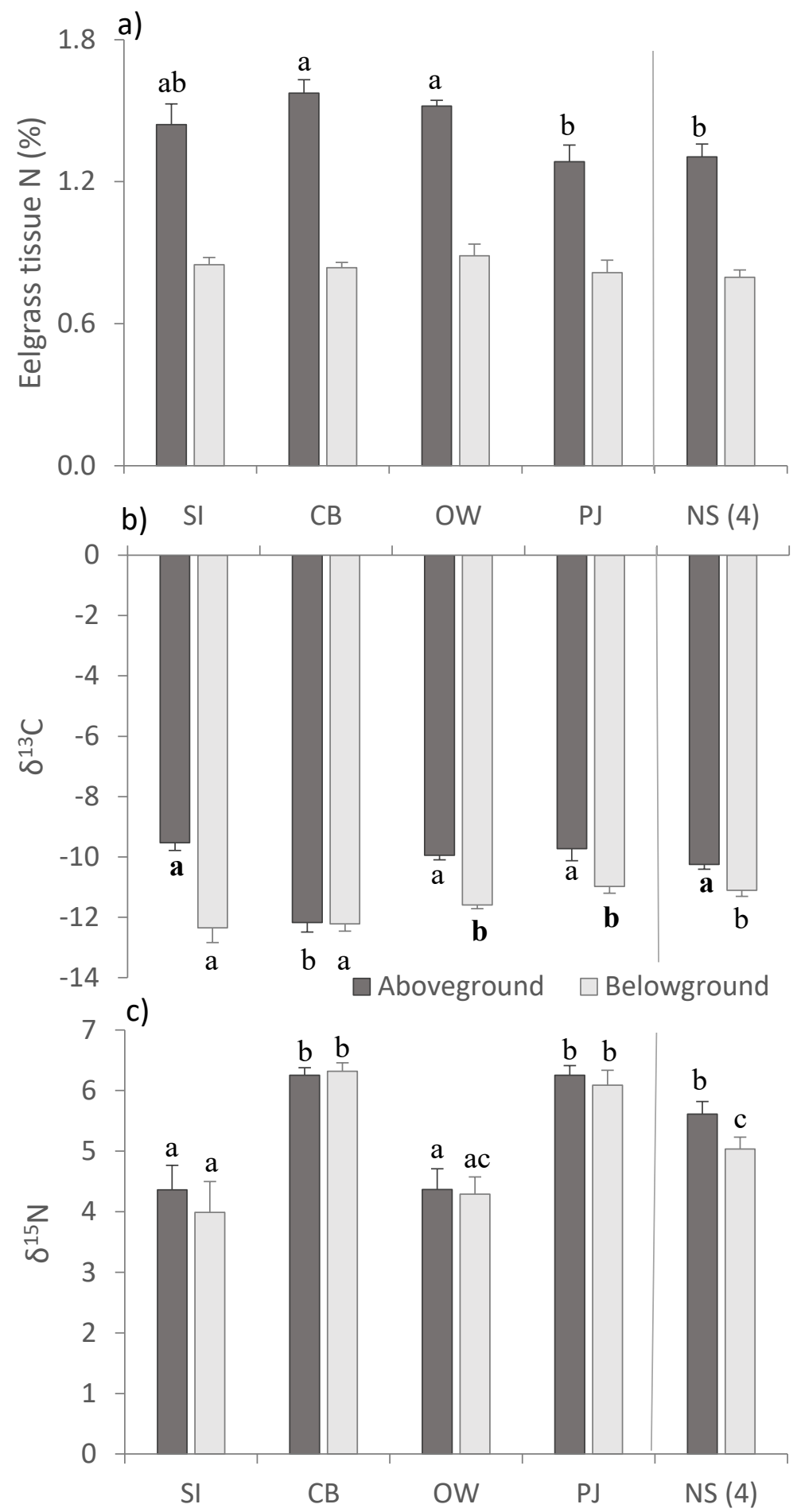


\section{Figure 4 (on next page)}

Eelgrass canopy structure (mean $\pm \mathrm{SE}$ ) across the four study sites.

From left to right: increasing distance from farm and PJ reference site, and an average of the other NS sites for comparison: a) shoot density, b) canopy height, c) percent cover, and d) above- and belowground biomass. Lower case letters indicate significant differences ( $p \leq$ 0.05. If the lower-case letters in the same group are bolded, there is a marginally nonsignificant difference between those sites (i.e. p-value between 0.05-0.1) for that variable. Number in brackets beside NS indicates the number of sites included in mean and statistical analyses. Refer to Table 1 for site abbreviations and details. 

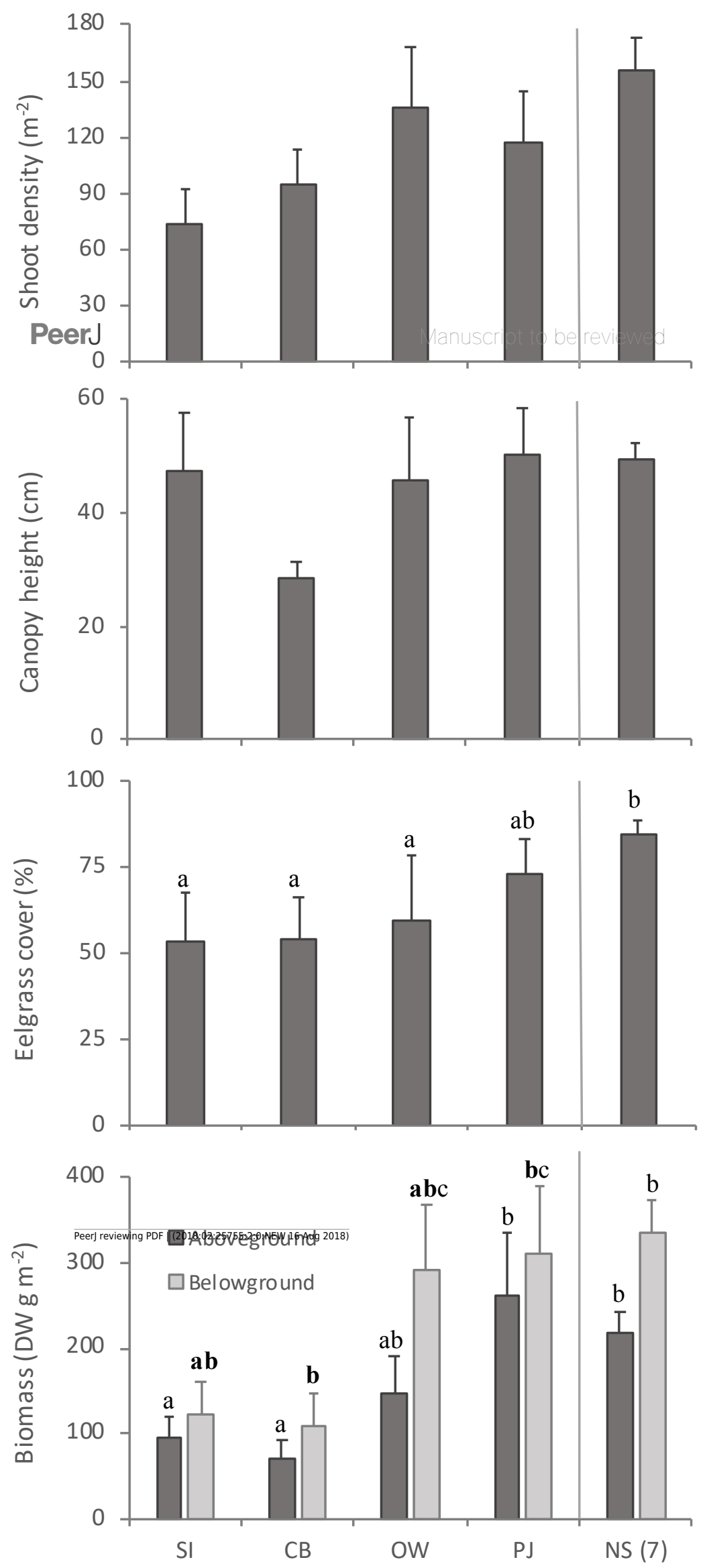
Figure $\mathbf{5}$ (on next page)

Summary measures (mean $\pm \mathrm{SE}$ ) of the macroinfauna community across the four study sites.

From left to right: increasing distance from farm and PJ reference site, and an average of the other Nova Scotia (NS) sites for comparison: a) total abundance, b) total biomass, and c) species richness. Lower case letters indicate significant differences $(p \leq 0.05)$. If the lowercase letters in the same group are bolded, there is a marginally non-significant difference between those sites (i.e. p-value between 0.05-0.1) for that variable. Number in brackets beside NS indicates the number of sites included in mean and statistical analyses. Refer to Table 1 for site abbreviations and details. 

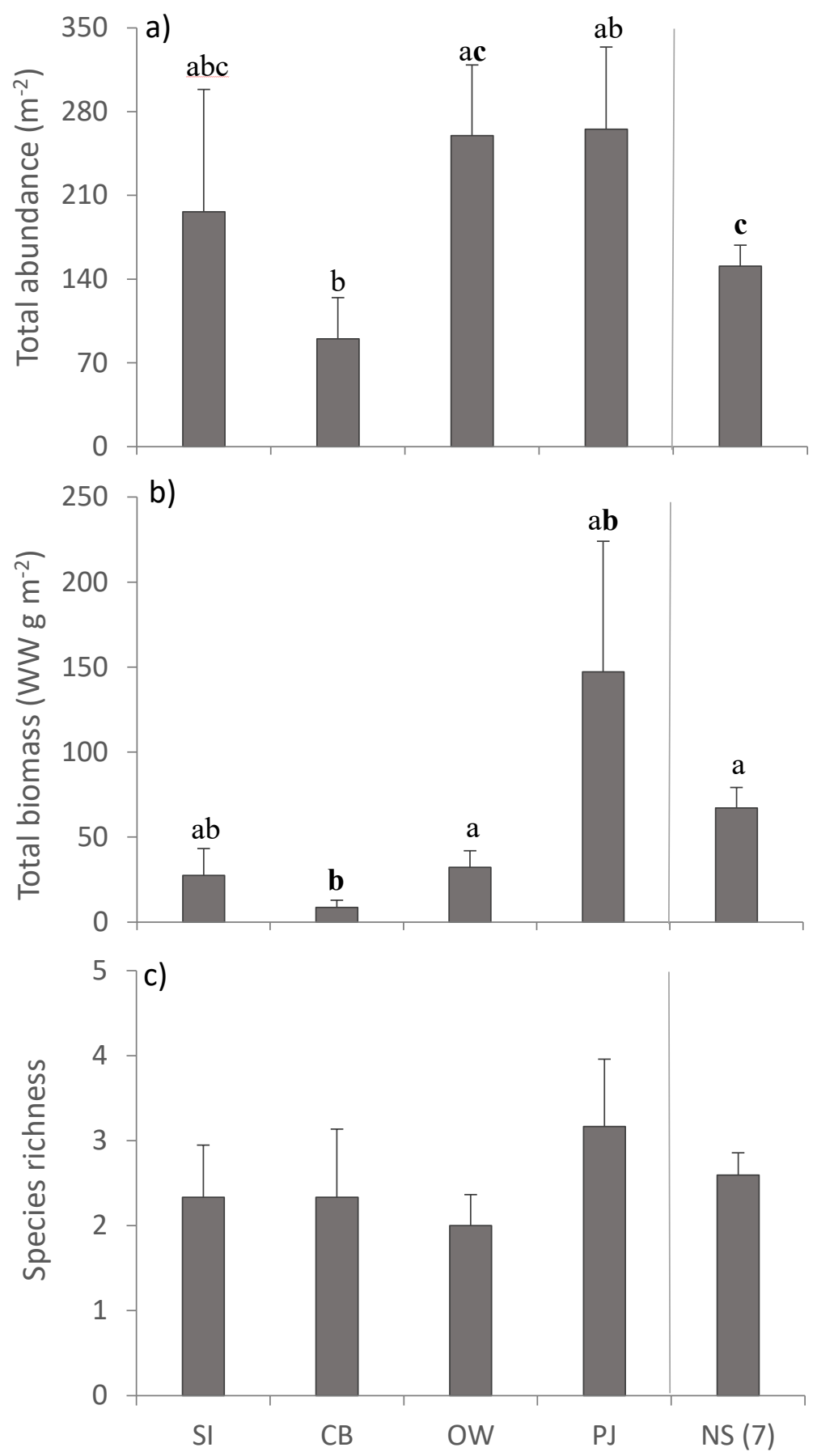
Figure 6 (on next page)

Abundance-biomass comparison $(A B C)$ curves using cumulative dominance for infauna species for the four study sites at increasing distances from the finfish farm in Port Mouton Bay.

a) Spectacle Island (SI), b) Carters Beach (CB), c) Old Wharf (OW), and d) the reference site Port Joli Bay (PJ) in Nova Scotia, Canada. 


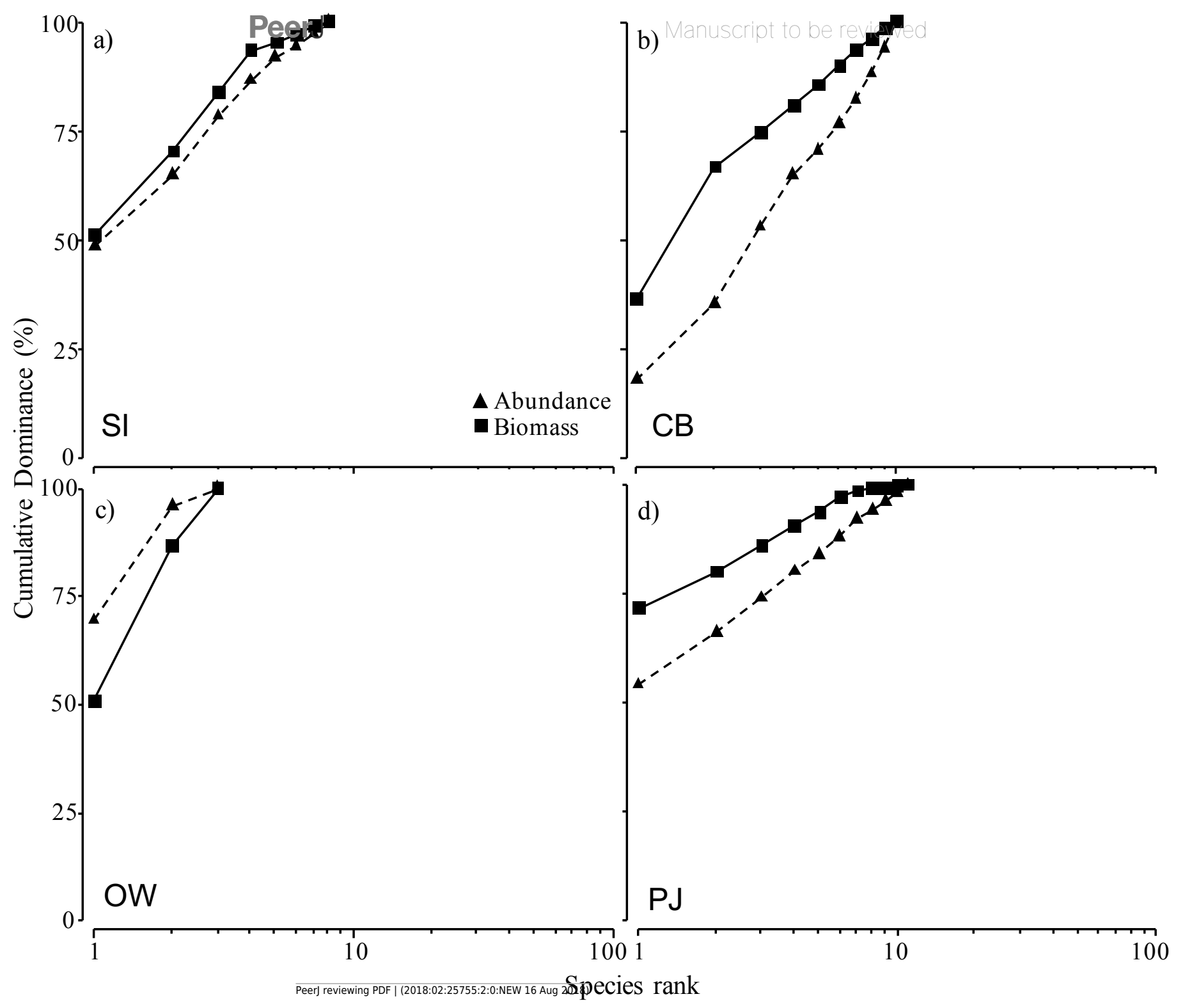


Figure 7 (on next page)

Cluster analysis using infauna community centroids.

Based on a) abundance and b) biomass as well as c) nMDS with overlaid clusters of all environmental, eelgrass tissue and eelgrass canopy variables as well as total infauna abundance, biomass and richness at the four study sites and an average of the other NS sites for comparison along the Atlantic Coast of Canada. See Table 1 for site abbreviations and details. Distance in panel c) refers to the Euclidean distance between centroids. 


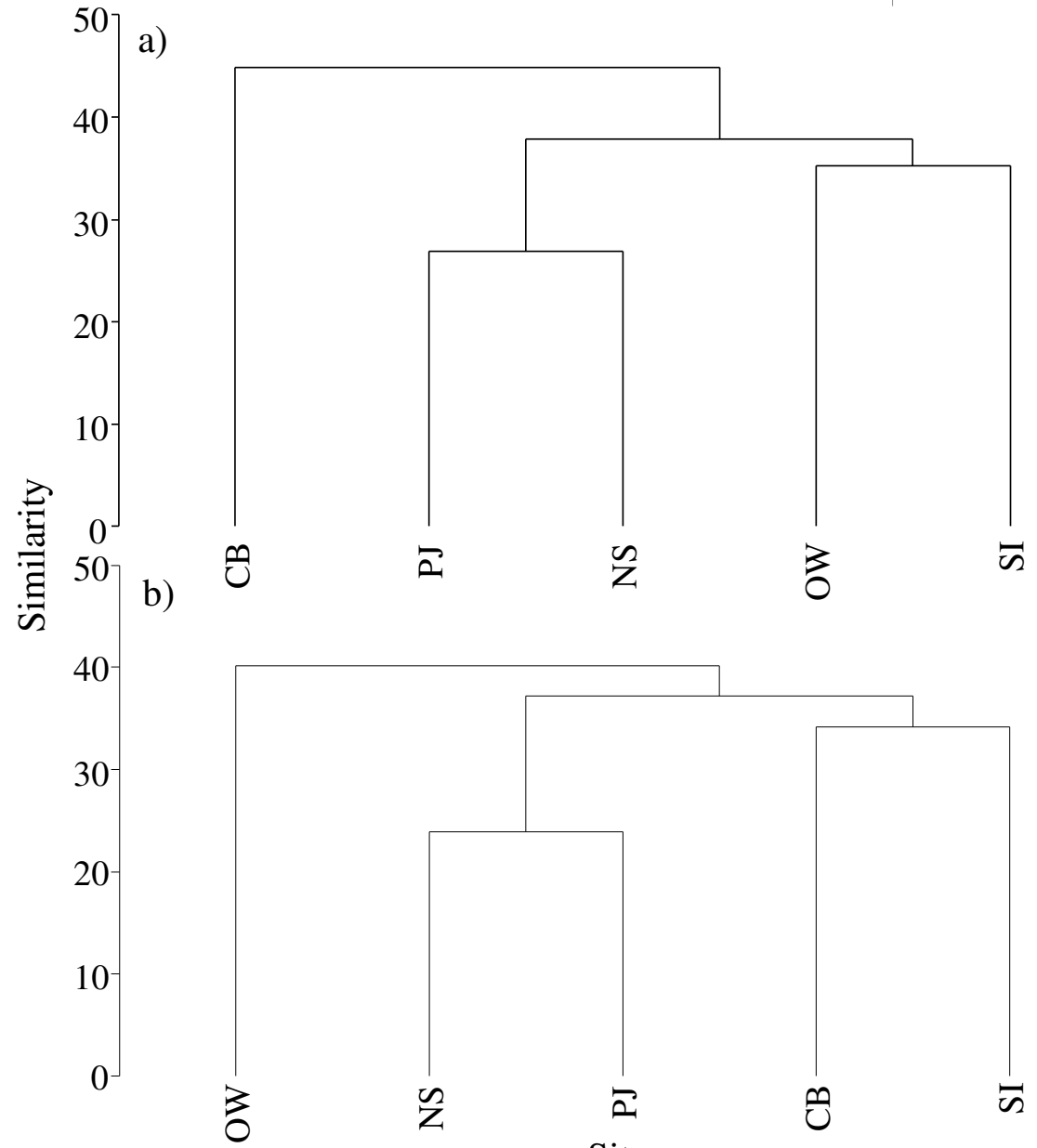

Sites

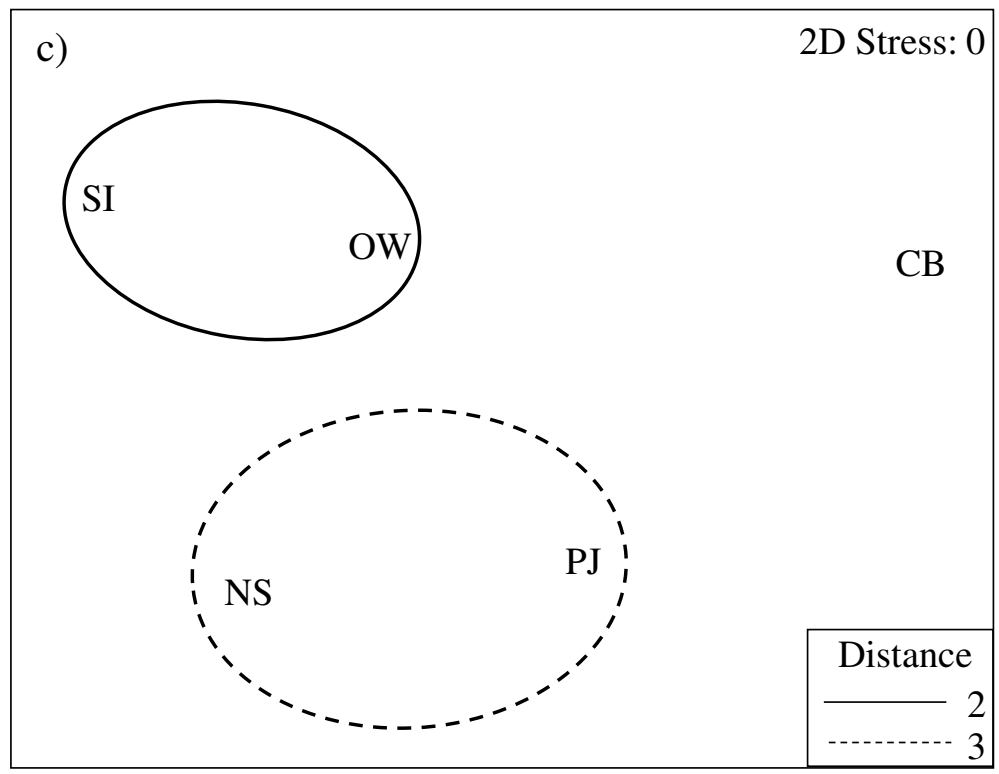

